\title{
Not Whether, but Where? Pell Grants and College Choices
}

\author{
Celeste K. Carruthers and Jilleah G. Welch*
}

May 2015

\begin{abstract}
We identify the effect of initial Pell grant eligibility on college enrollment and college choice, drawing on the enrollment decisions of four cohorts of Tennessee high school graduates and discontinuities in Pell eligibility as a function of federal formulas. Consistent with prior work, we find no evidence that marginal Pell eligibility increases college-going. We go on to show that just meeting the Pell cut-off has little bearing on where students choose to enroll, in terms of sector or quality dimensions. Below the threshold, where applicants are needier and the grant is more generous, students sort into colleges with modestly higher published tuition, on the order of 12 14 cents per dollar of Pell aid. And yet, no other measure of college quality or college selectively significantly diverges from the counterfactual. We conclude that Tennessee's traditional-aged students do not use the Pell grant as a tool to shop among college options in ways that systematically improve enrollment outcomes.
\end{abstract}

JEL: I22, I23, H75

Keywords: Education Policy, Higher Education, Financial Aid

*Carruthers: University of Tennessee, 702 Stokely Management Center, Knoxville, Tennessee 37996-0570, carruthers@utk.edu. Welch: University of Tennessee, 721A Stokely Management Center, Knoxville, Tennessee 379960570,jgwelch@vols.utk.edu. We are grateful for thoughtful comments and suggestions from David Sjoquist and panel participants at the 2014 Southern Economic Association meetings. Opinions and findings reported in this study do not necessarily reflect the views of the Tennessee Higher Education Commission. All errors are our own. 


\section{Introduction}

Over 9.4 million students received Pell grants, the largest source of federal grant aid in higher education, in the 2011-2012 academic year, amounting to $\$ 33.6$ billion in expenditures (U.S. Department of Education, 2012). This extensive grant program intends to increase access to college for financially constrained students, but research shows that the Pell grant has little to no positive impact on college enrollment or persistence (Hansen, 1983; Kane, 1995; Bettinger, 2004; Rubin, 2011), with notable exceptions provided by older, non-traditional students (Seftor \& Turner, 2002). The idea that traditional student demand for college is insensitive to Pell eligibility is not altogether surprising, for three reasons. Foremost, the application process for federal financial aid is complex and can stretch well into a student's senior year of high school, which weakens and delays the communication of aid eligibility to students on the margin of going to college (Dynarski \& Scott-Clayton, 2006, 2008; Dynarski \& Wiederspan, 2012; Dynarski et al., 2013). Easing this process meaningfully increases college enrollment (Bettinger et al., 2012). Second, institutions observe Pell eligibility at the same time as applicants, and they may capture a portion of federal funds by reducing institutional aid (Turner, 2014). And third, marginal Pell eligibility is associated with a fairly small grant, so local treatment effects could understate the impact of Pell grants more broadly. With these ideas in mind, two of the remaining questions about Pell eligibility and college-going center around students' choice of college, conditional on enrollment, and treatment effects for Pell grants larger than the modest scholarship available at the beginning of the phase-in range.

Using data on four cohorts of Tennessee high school graduates from the classes of 2006-2009, we utilize discontinuities in Pell eligibility along continuous values of "expected family contribution," a relatively opaque construct of federal aid processing, to estimate the impact of Pell grants on the extensive margin of college enrollment, and we go on to examine whether Pell eligibility affects where a student chooses to enroll, in terms of college sector and college quality. ${ }^{1}$ Are Pell recipients more inclined to enroll out-of-state? Are students receiving the Pell more likely to attend four-year universities rather than two-year colleges? Do Pell recipients attend higher quality insti-

\footnotetext{
${ }^{1}$ Throughout the study we use "college quality" interchangeably with "college selectivity," although we acknowledge that selectivity measures do not equate with institutional value added.
} 
tutions? To date, researchers have exploited the Pell eligibility threshold to examine on-time college enrollment (Rubin, 2011) and institutional aid (Turner, 2014), but it is not yet known whether Pell grants help to shape college choices. One reason for this gap in the literature is the rare confluence of data on complete cohorts of high school graduates, linked to both college enrollment outcomes and detailed data from financial aid applications. We draw from linked administrative data on Tennessee's public high school graduates that makes all of the necessary connections for a regression discontinuity analysis of college enrollment behavior and Pell eligibility.

Other aid programs have been shown to affect college choice, sometimes with unintended consequences. Bruce \& Carruthers (2014) find that the Tennessee HOPE scholarship, a broadbased merit scholarship, induces a small substitution effect towards four-year colleges and away from two-year colleges for marginally eligible students, and Goodman (2008) and Cohodes \& Goodman (2014) find that students favor in-state public colleges rather than higher quality private or out-of-state colleges in response to merit-based tuition waivers in Massachusetts. There is a fundamental difference between Pell grants and merit aid, however, that may dampen the effect of Pell on college choice. Eligibility criteria for merit aid programs are widely publicized and tied to standardized test scores or grade point averages. Students are well-informed as to their merit aid eligibility, sometimes long before they start applying to college. Eligibility for the Pell grant, by contrast, is much less transparent and students are notified late in twelfth grade.

In addition to characterizing the effect of Pell aid on college choices, we extend the literature in a second way by assessing whether the local impact of the Pell grant generalizes away from the eligibility threshold, where students are needier and where the grant is more generous. We extrapolate treatment effects below the eligibility cut-off based on the relationship between college enrollment and students' observable characteristics just above the cut-off (Angrist \& Rokkanen, forthcoming).

Consistent with previous work, our findings indicate that Pell eligibility does not significantly impact college enrollment per se for traditional-aged students. Moreover, we find little evidence that applicants use Pell eligibility to shop among college options. With rare exceptions, passing the Pell eligibility threshold has no impact on college sector or college quality. The exceptions are thus: we find that (1) marginally Pell-eligible males enroll in more selective colleges relative to 
marginally ineligible males, (2) females substitute into out-of-state four-year public colleges upon gaining Pell eligibility, and (3) Pell-eligible students enroll in institutions where tuition and fees are modestly higher than the counterfactual. But these findings are economically small, statistically imprecise, or sensitive to bandwidth and specification changes. We conclude that Pell grants the largest need-based aid vehicle in the United States - have no discernible impact on whether traditional-aged students go to college and at best modest effects on where students go to college.

\section{Conceptual and Policy Framework}

The federal Pell Grant program initially began under Title IV of the Higher Education Act of 1965. The specific timeline of Pell grant determination illustrates how students might leverage the grant to shop among college options as well as the difficulties of doing so in reality. Students seeking to be eligible for the Pell as well as other federal grants, subsidized loans, or work-study programs must complete a Free Application for Federal Student Aid (FAFSA). Students begin to file FAFSAs in January for fall enrollment the same year, and colleges often require that high school seniors submit their FAFSA between February and March in order to be given priority for need-based institutional aid.

The FAFSA collects demographic information, federal income tax information, family size, the number of family members in college (excluding parents), and other financial data such as assets and untaxed income. Students indicate at least one college to receive the output of FAFSA processing. The 2006-2009 cohorts in our study could submit the FAFSA electronically or by mail. Up to four colleges could be listed on paper FAFSAs while online applications allowed for six, increasing to ten with 2009 applicants (U.S. Department of Education, 2007).

Once a student submits her FAFSA, the Central Processing System calculates her Expected Family Contribution (EFC). EFC is the amount that the student or her family are expected to provide for college expenses, based on ability to pay. To begin calculating EFC, allowances for taxes and basic living expenses are subtracted from the family's income to yield "available" income. The family's available income along with a percentage of net assets is divided by the number of dependents in college (including the applicant) to generate EFC. ${ }^{2}$ Within three days to three weeks

\footnotetext{
${ }^{2}$ There are actually six different EFC formulas according to the student's dependency status and whether the stu-
} 
after a student submits her FAFSA, the Central Processing System sends the student a Student Aid Report, and all schools listed on the student's FAFSA receive an Institutional Student Information Record. The Student Aid Report lists the student's FAFSA information as well as her EFC and potential Pell grant eligibility.

At this point a student is notified that she may be eligible for a Pell grant but she is not made aware of the amount. Pell grants are a simple function of EFC, and Pell-to-EFC schedules are published each year. In principle, students can easily find out what their Pell grant should be upon learning their EFC. But the Student Aid Report - the primary communication between the federal aid process and students - does not include this information. One reason for this omission is that each component of the EFC formula is subject to audit and verification by institutions, who are responsible for compiling aid packages for each admitted applicant.

Financial aid offices at each college where a student is admitted use the relayed Institutional Student Information Record to determine how much need-based aid she can receive based on the reported EFC. Students' need-based and merit-based aid is collectively bound by the relevant cost of attendance. The cost of attendance for a particular college includes tuition and fees, room and board, books and supplies, miscellaneous expenses, and child care or dependent care allowances. There is a maximum and a minimum Pell grant for eligible students and a maximum EFC for Pell eligibility. These criteria vary from year to year according to federal appropriations. Each year, Pell grant eligibility is a sharp function of a particular value of EFC. For instance, year 2006 applicants with EFC equal to $\$ 3,851$ were ineligible for Pell while applicants with EFC between $\$ 3,650$ and $\$ 3,850$ were eligible for a $\$ 400$ grant. Then for EFC values below $\$ 3,650$, the Pell grant increased one-for-one until the maximum Pell grant of $\$ 4,050$ was reached for applicants with zero EFC. ${ }^{3}$

Typically, admitted students receive letters in March or April from college financial aid offices specifying the amount of Pell grants and institutional scholarships they are eligible to receive if dent qualifies for a simplified formula. The dependency-based formulas are very similar and mainly differ by the percentages and allowances used. The simplified formula uses a reduced set of financial indicators and is available to families who are eligible to file a 1040A or 1040EZ tax form instead of the longer $1040 \mathrm{form}$, or who participate in means-tested federal benefits programs and have an adjusted gross income less than a specific amount $(\$ 49,999$ for 2012-2013).

${ }^{3}$ Minimum Pell awards were $\$ 400, \$ 890$, and $\$ 976$ for 2007, 2008, and 2009 applicants, respectively, and maximum Pell awards were $\$ 4,310, \$ 4,731$, and $\$ 5,350$. 
they enroll. A student's EFC and potential Pell grant is constant across her choice set of colleges, but financial aid packages will differ across institutions according to cost of attendance, college resources, and available state aid. The idea that Pell grants could help students choose between different colleges rests on the non-trivial assumption that students can jointly consider admissions and aid information from multiple schools when deciding where to enroll. The federal aid application timeline offers two ways to do this. When submitting the initial FAFSA, as noted, students can request that their financial details be sent to up to ten schools. After the initial application, students can add or delete schools from this list online, by mail, over the phone, or via the financial aid office of a prospective college. In practice, however, a majority of students list just one school on their FAFSA applications (Turner, 2014).

Could Pell grants lead students to choose more selective institutions? Theoretical expectations are unclear. Pell-eligible students can apply the same grant to any Title IV institution: two-year, four-year, public, private, in-state, or out-of-state. ${ }^{4}$ In that sense, Pell grants are conditional transfers that relax households' income constraint for college expenditures and other goods. Ignoring for a moment the institutional response to Pell aid, the grant may affect students' relative preferences for different colleges if demand for college quality is responsive to net price. If the returns to college are greater for those educated at more selective institutions ${ }^{5}$ then basic human capital theory holds that a rational applicant will leverage Pell aid into a more costly, more selective institution. $^{6}$

This simple prediction rests on students having complete information, but in reality they may be uninformed about colleges that make up their choice set, uncertain about their chance of success at a more selective institution, or otherwise unsure about the future benefits of a college education.

\footnotetext{
${ }^{4}$ There are rare cases where Pell awards are reduced for exceeding a school's cost of attendance.

${ }^{5}$ See Kane \& Rouse (1995) and Reynolds (2012) for evidence that labor market returns to four-year institutions dominate those for two-year community colleges, Goodman et al. (2015) for evidence that just meeting the academic threshold for four-year college admission increases the likelihood of bachelor's degree completion, and Hoekstra (2009) for evidence that just gaining admission to an anonymous and selective flagship university significantly increases earnings as a young adult. The question of returns to college quality is not settled, however: Dale \& Krueger (2011) find that ability bias explains all of the wage returns to college selectivity for white students and students with more educated parents.

${ }^{6}$ See Avery \& Hoxby (2004) for an overview of the human capital model specifically in the context of college choice. Rational agents calculate present discounted values for each potential college in their choice set and include the cost of college, grants, scholarships, loans, future earnings, consumption, etc. Then, a rational student chooses the school that maximizes the difference between the present discounted value of benefits and the present discounted value of costs.
} 
Moreover, the visage of a rational applicant is more nuanced than one who considers only net price and lifecycle income. Students sort into colleges based on a number of other factors: debt aversion, distance from home (Long, 2004), college amenities (Jacob et al., 2013), and so forth. And the price elasticity of demand for college quality is not readily understood - since the value of the Pell grant is de jure equivalent across institutions, Pell eligibility changes the relative price of institutions could actually lead students to favor less costly, less selective institutions. Consider the Alchian \& Allen (1967) theorem, usually applied to a consumer's decision to buy either a high quality or low quality version of the same good. When a fixed cost, typically a transportation cost, is added to both goods, the relative price of a high quality good decreases, leading consumers to purchase the higher quality good in spite of the overall price increase. By contrast, uniform Pell grants increase the relative price of more costly colleges, perhaps leading some students to favor less selective, less costly institutions. The "free ride" that a $\$ 5,000$ Pell grant affords at a community college, for instance, may have more salience than a $\$ 5,000$ discount at a four-year university.

Empirical evidence related to our question is less ambiguous than theory. Recent work has shown that gains in families' ability to pay for college - actual or perceived - lead students to select higher quality colleges. Lovenheim \& Reynolds (2013) find that rising home equity increases the probability a student attends a high quality institution, and this was especially true for students from low-income families. Hoxby \& Turner (2014) report on a randomized controlled trial that provided ACT and SAT test-takers with application fee waivers and information on net price at several different colleges, under the hypothesis that high-achieving, low-income applicants are not fully aware of the aid available to them at more selective institutions. The treatment effectively increased families' perceived ability to pay and led students to enroll in substantially better colleges at a cost of $\$ 6$ - 15 per student. But for administrative reasons outlined above, the effect of a Pell grant on families' budget constraint may be much less apparent than new housing wealth or an informative mailer.

Expectations from theoretical and empirical frameworks are further clouded when institutional responses are taken in consideration. Colleges publicize the rate of Pell-eligible students they enroll, a signal of economic diversity that may have intrinsic value to institutions and alumni. Nev- 
ertheless, colleges allocate institutional grants with full knowledge of applicants' Pell eligibility, and the grant may crowd out other sources of aid (Turner, 2014), yielding little difference in net price across a student's choice set.

The opaque and sharp nature of Pell eligibility as a function of EFC motivates a quasi-experimental analysis of the effect of Pell on college choices. But the timing and delivery of official Pell grant amounts, alongside uncertainty surrounding students' price sensitivity and demand for college quality, leads to ambiguous a priori expectations at and below the Pell grant threshold. In the reduced form, then, the empirical questions surrounding Pell grants and college choices necessitate a large and representative set of students making college decisions. With this in mind, we examine college enrollment choices for the universe of 2006-2009 Tennessee high school graduates filing FAFSA applications.

\section{Data and Methods}

Data on 2006-2009 Tennessee high school graduates and their FAFSA records are provided by the Tennessee Higher Education Commission, who match students to college enrollment outcomes using the National Student Clearinghouse. We merge information on college selectivity (the ACT scores of incoming classes, instructional expenditures per student, Carnegie class, and published tuition and fees) from the federal Integrated Postsecondary Education Data System (IPEDS). National Student Clearinghouse data on these four cohorts cover observed postsecondary enrollment

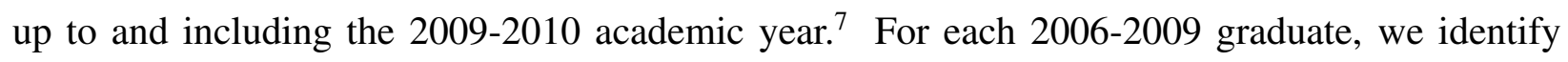
the first instance of a successful FAFSA (excluding dual enrollment) and link that application to college enrollment outcomes the following academic year. ${ }^{8,9}$

\footnotetext{
${ }^{7}$ The National Student Clearinghouse is a non-profit entity whose enrollment data cover, as of this writing, in excess of 98 percent of United States college students. Coverage tends to be narrower, but still over 90 percent, among Tennessee college students due to a preponderance of small religiously-affiliated colleges that do not participate in the Clearinghouse. We have no reason to expect that non-participation rates will affect results and/or vary discontinuously over the Pell eligibility threshold.

${ }^{8}$ This necessarily leads to imbalance across cohorts, in that we allow the 2006 cohort to wait up to four academic years after graduation to file a FAFSA and enroll in college, whereas we observe just one year after high school for 2009 graduates. As we show in the appendix, results are robust to conditioning on student covariates and cohort fixed effects. Additionally, in an unreported analysis, we find that results are robust to the omission of students whose first FAFSA application is more than one year after high school.

${ }^{9}$ The market for higher education is somewhat concentrated among Tennessee high school graduates, but not so much as to motivate a discrete choice model rather than regression discontinuity identification across a spectrum of
} 
From the starting-point sample of 2006 - 2009 Tennessee high school graduates, we omit 22 percent who do not file a FAFSA before 2011. This sample selection is regrettable but necessary to evaluate the Pell grant's impact on matriculation decisions. Pell eligibility is determined via FAFSA processing, so students who neglect to file an application are automatically ineligible. Moreover, the forcing variable used in regression discontinuity analyses - each student's expected family contribution - is unavailable for students without an application on record. Although results will not necessarily generalize to students who do not file for federal aid, findings allow for causal inference regarding financial aid eligibility and college choices among low-income students who are considering college.

Table 1 lists descriptive statistics for the FAFSA-filing sample as a whole, by subsequent college enrollment (Columns 1-2), as well as for the subset of students whose EFC falls within $\$ 3,000$ of Pell eligibility (Columns 3-4). Note that 80.5 percent of the bandwidth-restricted sample enrolled in college during the window of time between graduation and 2009-2010. This is considerably higher than the rate of college enrollment for Tennessee high school graduates a whole (63.5 percent among these four cohorts), which is a consequence of inherently higher rates of collegegoing among successful FAFSA filers. Table 2 lists summary statistics for college outcomes of interest, conditional on enrolling in college at all. We examine a mutually exclusive and exhaustive set of six college sector options, demarcated by control (public or private), state (in Tennessee or not), and level (two-year or four-year). We additionally examine nine measures of college quality and college selectivity, listed and summarized in the bottom portion of Table 2.

The specification for baseline regression discontinuity analysis takes the following form:

$$
Y_{i c}=\alpha+\beta_{1} P E L L_{i c}+\beta_{2} P E L L_{i c} *\left(E F C_{i c}-\bar{E}_{c}\right)+\beta_{3}\left(E F C_{i c}-\bar{E}_{c}\right)+\epsilon_{i c}
$$

where $Y_{i c}$ is a matriculation or institutional outcome for student $i$ in cohort $c, P E L L_{i c}$ is an indicator equal to one for students whose $\mathrm{EFC}$ is at or below the Pell eligibility threshold, and $\bar{E}_{c}$ is the relevant Pell eligbility threshold for cohort $c$. We limit the analysis to students whose nominal EFC falls within $\$ 3,000$ of the relevant Pell eligibility threshold, and we round EFC values to the nearest hundred. Robust standard errors are clustered by $\$ 100$ EFC bin. The appendix discusses college quality. The top five destinations for students in this sample draw 30 percent of college-going seniors, and the Herfindahl-Hirschman Index for all college destinations is 366. 
results under wider EFC aggregations, alternative bandwidths (narrower, optimal), the inclusion of controls, and the use of a quadratic rather than a linear function for the gap between $i$ 's EFC and the Pell eligibility threshold for $i$ 's cohort $\left(E F C_{i c}-\bar{E}_{c}\right)$.

Ours is a sharp regression discontinuity analysis, since Pell eligibility rates rise from zero to very nearly one hundred percent at the $E F C_{i c}=\bar{E}_{c}$ threshold. ${ }^{10}$ Figure 1 depicts Pell eligibility relative to the EFC cut-off alongside grantees' potential scholarship. ${ }^{11}$ The local average treatment effect estimate of Pell eligibility on $Y_{i c}$ is given by $\beta_{1}$ in Equation 1. The standard regression discontinuity identification assumption applies: in the absence of Pell grants, the propensity to enroll in different colleges would have varied smoothly around the EFC threshold.

We indirectly test the identification assumption in three ways. First, we follow McCrary (2008) and test for discontinuities in the density of EFC values around the threshold, finding that students do not appear to cluster on one side of the threshold. ${ }^{12}$ This implies that applicants are not strategically responding to the publicly available (albeit, complex) EFC formula to gain Pell eligibility. Second, we estimate discontinuities in pre-college student characteristics like gender, race, ethnicity, and parental education. Results are listed in the top portion of Table 3. Other than a significant 1.6 percentage point decline in the likelihood of one's father having a college education, we see no indication that students below the Pell threshold were very different from students just above the threshold. Another way to test the fundamental identification assumption is to estimate college enrollment outcomes as a function of students' observable characteristics (listed in Table 1) and then examine whether predicted outcomes shift at the threshold. The bottom portion of Table 3 lists findings from that exercise, where we show that expected enrollment outcomes vary smoothly over the Pell eligibility threshold.

As noted in Section 2, marginal Pell eligibility yields a modest grant, which may limit the extent to which the students who drive local treatment effects realistically use the Pell to shop for

\footnotetext{
${ }^{10}$ Estimates of Equation 1 for reported Pell eligibility point to a first-stage discontinuity of between 99 and 100 percent.

${ }^{11}$ We observe official Pell eligibility in the FAFSA data on hand, but not the amount of the grant students were ultimately awarded. Panel I of Figure 1 represents students' actual, reported eligibility, whereas Panel II depicts the grant that students would have been eligible for according to their EFC. Pell grants, worth no more than $\$ 5,350$ for these cohorts, are rarely scaled back for exceeding the cost of attendance constraint, which generally measures in the tens of thousands of dollars.

${ }^{12}$ The $\log$ difference in bin height is estimated to be 0.060 at the eligibility threshold with a standard error of 0.045 .
} 
different colleges. A variety of methods are available to estimate treatment effects away from an eligibility threshold based on extrapolations of $Y_{i c}=f\left(E F C_{i c}-\bar{E}_{c}\right)$ functional forms or based on changes in the $f(\cdot)$ slope at the threshold. These hinge on assumptions about counterfactual $f(\cdot)$ in the absence of treatment. Rather than make assumptions about the relationship between counterfactual college choices and the running variable, we pursue a method proposed by Angrist \& Rokkanen (forthcoming) that first explains that relationship using exogenous characteristics of subjects, and then predicts counterfactual outcomes as functions of those characteristics. Our identifying assumption is thus: in the absence of Pell, outcomes would be mean-independent of $E F C_{i c}-\bar{E}_{c}$ when conditioned on a set of $X_{i c}$ student variables.

This conditional independence assumption is tested using the following specification, with the sample limited to Pell-ineligible students with EFC values up to $\$ 3,000$ above the cut-off: ${ }^{13}$

$$
Y_{i c}=\alpha+\pi\left(E F C_{i c}-\bar{E}_{c}\right)+X_{i c} \gamma+\varepsilon
$$

A parsimonious set of $X_{i c}$ observables describing student $i$ are used to model college enrollment choices. If the running variable $E F C_{i c}-\bar{E}_{c}$ is an insignificant determinant of enrollment outcomes, conditional on $X_{i c}$, we can more confidently argue that $\hat{Y}_{i c}$ predictions below the eligibility threshold based on parameter estimates from students above the threshold are adequate counterfactual outcomes. Our task, then, is to explain enough of the variation in Pell-ineligible students' college choices to render the conditional correlation with distance from the cut-off null. To do so we include in $X_{i c}$ measures of demographics (gender, Caucasian race), families' ability to pay (real adjusted gross income and the ratio of EFC to adjusted gross income), parental education (binary indicators for mothers' college education and fathers' college education), and student ability and commitment to college (first ACT composite score, the number of ACT attempts, indicators for missing ACT data). We find that $\pi$ estimates from Equation 2 for the set of college sector and college quality outcomes are generally small and insignificant (see Table 10 in the appendix). Predictions from Equation 2 are extrapolated as counterfactual outcomes below the Pell eligibility threshold using linear re-weighting estimators (Kline, 2011).

\footnotetext{
${ }^{13}$ We limit the conditional independence test to ineligible students above the Pell threshold since the Pell grant treatment grows as EFC falls. Note that this is a weaker test than that articulated by Angrist \& Rokkanen (forthcoming), who apply this method to a setting where outcomes are assumed to be mean-independent of the running variable on both sides of the threshold.
} 


\section{Results}

\subsection{The impact of Pell eligibility on college enrollment and the choice of college sector}

Figure 2 summarizes our findings for the effect of Pell eligibility on any college enrollment. Point estimates and standard errors for $\beta_{1}$ in Equation 1 are listed above each figure. Echoing earlier work that utilizes a similarly sharp identification strategy, but in a survey setting with less statistical power (Rubin, 2011), we find no discernible increase in college-going below the Pell eligibility threshold. On the contrary, we observe a marginally significant decline in college-going among white FAFSA-filers, although as we show in the Appendix, this counter-intuitive result is sensitive to modifications of the Equation 1 specification.

One reason that Pell eligibility might be ineffective at pushing marginal college students to enroll is that eligibility is communicated to students fairly late in their senior year of high school, after students have committed to enrolling (or not enrolling) in college. This would also tend to work against Pell as a tool for students choosing between different colleges, but in principle applicants have leeway to consider aid packages from multiple schools, and to date, the idea that Pell eligibility helps students shop among their choice set is untested. With this in mind, we limit the sample to college-going students and estimate Equation 1 for a mutually exclusive and exhaustive set of six college sectors. Results - for the entire sample of college enrollees and subsamples divided by gender and race - are listed in Table 4 .

Column (1) lists point estimates and robust standard errors for $\beta_{1}$ from Equation 1, applied to the college sector choices of all college enrollees in the four-cohort sample of Tennessee high school graduates. Column (1) results are also depicted in Figure 3. We find no significant discontinuities in students' enrollment behavior broadly, although there are three marginally significant results for subsamples that are worthy of note. First, males are 0.4 percentage points more likely to enroll in a private two-year college below the Pell eligibility threshold. These are typically forprofit sub-baccalaureate colleges. Though the point estimate is small and weakly significant, it represents 80 percent of the share of students enrolling in this sector. Second, females are somewhat less likely to enroll in an in-state four-year college and somewhat more likely to enroll in an 
out-of-state four-year college just below the Pell threshold, relative to students who are marginally ineligible for Pell. As we show in the Appendix, these findings are sensitive to wider bandwidths but otherwise robust across alternative specifications.

Among the thirty estimates presented in Table 4, we might expect three to fall within the 10 percent level of statistical significance. Even if we consider them to be genuine consequences of Pell eligibility, they do not amount to strong evidence that Pell eligibility helps students shop across college options or enroll in better colleges than they would have otherwise.

We note an important observation from Figure 3 before moving on to results for student decisions in terms of college quality. The slope of some outcomes with respect to the running variable changes noticeably at the threshold in ways that suggest that the elasticity of student responses with respect to the grant value, rather than grant eligibility, favors more selective colleges. In particular, enrollment in Tennessee two-year community colleges appears to become less likely for needier students who qualify for larger Pell grants, and enrollment in out-of-state four-year public universities becomes more likely. Since the grant rises dollar-for-dollar in this range of EFC, one way to quantify changes in slope is to interpret $\beta_{2}$ in Equation 1 as a regression kink estimate of student responses to aid. ${ }^{14}$ We do not pursue a regression kink design here because a number of predetermined covariates listed in Table 3 also exhibit a small but significant change in slope proximate to the eligibility threshold, as do regression-adjusted enrollment outcomes predicated on those covariates. ${ }^{15}$ Rather, in Section 4.3 we present results based on supra-threshold extrapolations that condition on student observables.

\subsection{Pell and the quality of college}

Next, we examine the potential effect of Pell eligibility on the quality of college chosen, as proxied by nine institutional characteristics drawn from IPEDS: the 25th and 75th percentiles of enrollee ACT scores, per-student instructional expenditures,${ }^{16}$ student-faculty ratios, graduation rates,

\footnotetext{
${ }^{14}$ Regression kink methods are described in detail by Card et al. (2012).

${ }^{15}$ Nevertheless, conclusions from regression kink analyses are in accord with those discussed in Section 4.3.

${ }^{16}$ Instructional expenditures per student are also available in the Delta Cost Project Database. The Delta Cost Project database consists of IPEDS financial data for colleges, but the data have been adjusted to account for changes in reporting and accounting standards over time. Results and robustness checks when using instructional expenditures per FTE from Delta Cost are consistent with those when using instructional expenditures directly from IPEDS.
} 
Carnegie class, tuition and fees for in-state residents, tuition and fees for out-of-state residents, and lastly, tuition and fees conditional on students' actual residency (i.e., students attending Tennessee institutions are assigned in-state tuition and students attending out-of-state institutions are assigned out-of-state tuition). Results are listed in Table 5. We see little evidence in Column (1) to suggest that the broad population of Tennessee college-goers systematically sorts across college quality domains in response to Pell eligibility. All of the point estimates in Column (1) of Table 5 are consistent with the idea that students move to higher-quality institutions because of Pell, but none of these estimates are statistically significant at conventional levels.

Columns (2) through (5) of Table 5 lists results by gender and race. The standout result from this stratification is that male college choices may be somewhat sensitive to Pell eligibility. Marginally Pell-eligible males attend institutions with a slightly higher interquartile range of student body ACT scores, by 0.22 composite points at the 25 th percentile and 0.31 points at the 75 th percentile. These discontinuities reflect 1.2 percent and 1.3 percent, respectively, of bandwidthrestricted samples means for these selectivity measures (8.1 and 10.0 of their respective standard deviations). We also detect weakly significant discontinuities in student-faculty ratios for males, but not for other subsamples. Of the fifteen college outcomes we examine in this study, results for the interquartile ACT range of males' college choices are thus far the strongest evidence for quality upgrading at the Pell eligibility threshold. The magnitude of ACT improvements at males' chosen colleges may yield significant returns that outweigh the direct cost of Pell support. ${ }^{17}$ However, males' evident quality upgrading appears to be very local to the Pell eligibility threshold. As we show in the appendix, Table 5 Column (2) results for ACT interquartiles do not generalize to lower EFC values.

\footnotetext{
${ }^{17}$ Hoekstra (2009) finds that marginally successful applicants to a selective flagship university earn 18 - 28 percent more, annually, as 28 - 33 year-olds than marginally ineligible applicants. The anonymous flagship drew freshmen scoring 65 points higher on the SAT than the next most selective in-state university, a difference equivalent to 6.4 percent of the mean among the relevant cohort per The College Board (1996, Table 4-2). Here, we find that white Pell-eligible males sort into colleges with higher ACT scores by $1.2-1.3$ percent of the mean. If, in agreement with Hoekstra (2009), this results in 3.4 - 5.3 percent gains in annual earnings for affected students, the value of additional earnings could amount to $\$ 37,000$ - $\$ 57,000$ over a 30 -year career, assuming a 3 percent discount rate and baseline weekly earnings of $\$ 1,101$ (the average weekly earnings for full-time and salary workers with a bachelor's degree over age 25, per the Current Population Survey). This dominates by a factor of $5-8$ the short-term cost of Pell grants (typically $\$ 2,120$ per year in this window).
} 


\subsection{Treatment effects away from the eligibility threshold}

With the notable exception of gender-specific findings for certain college measures, regression discontinuity results imply that Pell eligibility and Pell awards have little bearing on students' demand for college overall, nor on their relative demand across the spectrum of college quality and selectivity. This may be because the marginal Pell grant is somewhat modest, $\$ 400$ for the first two cohorts in our sample, and $\$ 890$ and $\$ 976$ for subsequent cohorts. ${ }^{18}$ It may be the case that null local treatment effects do not generalize, and that needier students who qualify for larger Pell grants well below the threshold are more affected.

Therefore, we follow a method proposed by Angrist \& Rokkanen (forthcoming) and examine treatment effects below the eligibility threshold. As outlined in Section 3, we first focus on Pell-ineligible students whose EFC falls within $\$ 3,000$ of the Pell cut-off and estimate college outcomes as a function of exogenous student characteristics listed in Section 3. We then map parameter estimates to Pell-eligible students with EFC values up to $\$ 3,000$ below the threshold. Treatment-on-the-treated effects are taken to be the average difference between observed and predicted outcomes, with standard errors calculated following Kline (2011).

Key results are depicted in Figure 4 for any college enrollment, Figure 5 for college sector outcomes, and Figure 6 for college quality outcomes (including the only four with statistically significant treatment effects). Circles represent observed student outcomes and "X" markers represent counterfactual estimates, summarized by $\$ 100$ EFC bin. Treatment effects and standard errors are listed under each figure heading. We find no significant treatment effect on college-going below the Pell cut-off (Figure 4), and no meaningful effect on students' chosen college sector (Figure 5). A possible exception is found in the sub-figure for private four-year enrollment, where we see a weakly significant 1.1-point positive treatment effect below the threshold.

Regarding the quality of colleges chosen (Figure 6), we do not see a significant gap between observed and counterfactual outcomes for any measure of selectivity or quality except for published tuition and fees and colleges' graduation rate. Sub-threshold treatment effects indicate that Pelleligible students attend institutions with higher tuition and fees than they would have otherwise, by

\footnotetext{
${ }^{18} \mathrm{~A}$ modal finding in the early financial aid literature is that each $\$ 1,000$ yields a 4-percentage-point increase in college-going (see Deming \& Dynarski (2010) for a review), so despite the small initial value of the grant, our null results run counter to expectations of 2 - 4 percentage-point gains in college-going as a result of marginal eligibility.
} 
\$261 on in-state schedules and \$299 on out-of-state schedules. Within this range of Pell-eligible students, grants were $\$ 2,120$ on average. This means that each dollar of Pell aid was potentially offset by 12.3 - 14.1 cents of higher tuition, without considering reductions in out-of-pocket costs from institutional grants. But when we look at published tuition and fees at each students' institution and condition on their residency, it is harder to make the case that Pell grants give students more buying power. Residency-based tuition is higher than the counterfactual, but by a weakly significant \$214. Pell-eligible students also attend institutions with a higher graduation rate, but estimated treatment effects are small and weakly significant $(0.54$ percentage points is 2.8 percent of a standard deviation among college-going students in this bandwidth).

\section{Discussion}

The effect of Pell grants on traditional students' college-going has been found to be small or null (Hansen, 1983; Kane, 1995; Bettinger, 2004; Rubin, 2011), but to date, it is unclear whether Pell eligibility affects where students enroll. We extend the need-based financial aid literature in this direction, utilizing unique administrative data that links high school graduates to detailed financial aid data as well as college enrollment outcomes. Based on discontinuous changes in Pell eligibility along the schedule of expected family contribution, we find little evidence to suggest that students use the Pell as a tool to expand or shop among their choice set of colleges. Scattered results in favor of quality upgrading among marginally Pell-eligible students include females' substitution out of state and males' choice of more selective colleges at the threshold, but these results are economically small, sensitive to specification, or statistically imprecise.

Perhaps our most intriguing finding regards the tuition and fees of Pell-eligible students' selected institutions. By examining treatment effects below the threshold, we find support for the idea that students sort into more costly colleges as a consequence of successively more generous Pell aid. It is worth noting, however, that we cannot discern whether this arises from student-led demand for more expensive colleges, or from institution-led demand for Pell-eligible students. Moreover, higher tuition does not necessarily equate with higher quality, and several other dimensions of college selectivity and quality change very little (e.g., graduation rates) or not at all (instructional expenditures, Carnegie research status) at and below the eligibility threshold. 
One likely explanation for our null results lies with the way in which Pell eligibility and Pell amounts are announced to students. The same opaque and formulaic eligibility criterion that motivates sharp regression discontinuity analysis may hinder applicants' awareness of the program. Moreover, results from financial aid applications are delivered late in the senior year of high school, when many college plans are already in place. More salient changes in families' perceived ability to pay have been shown to lead to quality upgrading (Lovenheim \& Reynolds, 2012; Hoxby \& Turner, 2014), although the theoretical implications of a uniform change in net price throughout the college quality spectrum remain unclear. And of course, the Pell-induced price differential is blunted to the extent that Pell grants crowd out institutional aid. Though we cannot deconstruct the relative contributions of these four candidate mechanisms, we can conclude that their collective effect is to rule out Pell grant eligibility as a systematic factor in college choice.

\section{Appendix: Additional Tables and Robustness Checks}

This appendix includes robustness and specification checks for our main regression discontinuity analyses of Pell eligibility and college outcomes. Additionally, results for treatment effects away from the eligibility threshold are presented for subsamples of students as well as results for our implicit test of the bounded conditional independence assumption.

Table 6 lists $\beta_{1}$ estimates for any college enrollment across five different specifications of Equation 1, enumerated A - F. Model A is our baseline specification, where the sample is limited to students whose EFC falls within $\$ 3,000$ of the Pell eligibility cut-off, the EFC running variable is rounded to the nearest $\$ 100$, and covariates other than EFC functional forms are excluded. Results in the top row of Table 6 can also be found in Figure 2. Model B adds a rich set of students' pretreatment observables, summarized in Table 1, as well as cohort fixed effects. Model C returns to the specification without controls but narrows the bandwidth to $\$ 1,500$. Model $\mathrm{D}$ estimates Equation 1 under the optimal bandwidth for each subsample, following Imbens \& Kalyanaraman (2012). Out of concern that $\$ 100 \mathrm{EFC}$ bins are too narrow and introduce more noise than is necessary, in Model E we aggregate the running variable to $\$ 500$ EFC bins and re-estimate Equation 1. Lastly, Model $\mathrm{F}$ uses a quadratic rather than a linear function for the gap between $i$ 's EFC and the Pell eligibility threshold for $i$ 's cohort $\left(E F C_{i c}-\bar{E}_{c}\right)$. As we show in Table 6, these modi- 
fications to the baseline specification do not affect our conclusions regarding Pell eligibility and college enrollment per se. Discontinuities in college-going are generally insignificant, with some counterintuitively negative point estimates that do not replicate across models A - F.

We do not estimate Equation 1 under bandwidths that include the full support of Pell eligible EFC values, for reasons apparent in Figure 7. The top panel of the figure illustrates $\beta_{1}$ point estimates and confidence intervals for bandwidths ranging from $\$ 500$ - $\$ 20,000$. Treatment effect estimates for college enrollment are significantly positive for bandwidths of about $\$ 5,000$ and greater. But the bottom panel of Figure 7 illustrates why that is the case. By construction, EFC is bounded by zero, and bandwidths that include students with zero EFC - who constitute a large share of Pell-eligible students and who tend to enroll in college at a significantly lower rate than their peers - overstate the linear discontinuity estimate at the eligibility threshold. These models let zero-EFC and \$100-EFC students have too much influence over discontinuity estimates at the cut-off.

Tables 7 - 9 depict regression discontinuity estimates for college sector and college quality outcomes, overall and by gender. For college sector outcomes we add one specification check to models A - F described above: namely, we include students who do not enroll in college in the estimating equation. ${ }^{19}$ In Table 7 we show that null college sorting results for the sample overall generally hold up to variations of Equation 1. Exceptions are found in Column (5) regarding published tuition and fee discontinuities within the optimal bandwidth, but we note that these bandwidths (reported in brackets in Column (5)) are quite large and include zero-EFC students. Larger EFC bins render more precise point estimates in Column (6) for receiving institutions' ACT interquartile range, student-to-faculty ratio, graduation rate, and residency-based tuition. Turning to Tables 8 and 9 and comparing Columns (1) and (6), we see that these alternative EFC aggregations underscore the same subsample results that our baseline model detects.

Table 8 lists college choice estimates for males, and we find that the positive treatment effects on college selectivity (in terms of the ACT interquartile range of males' selected colleges) are robust to each alternative, albeit with much less precision under the narrow bandwidth. Table 9 repeats the same exercises for the female subsample, and we note that females' weakly signifi-

\footnotetext{
${ }^{19}$ College quality outcomes are of course undefined for these students, so Column (1) and (2) results for the nine IPEDS college quality measures are identical.
} 
cant substitution between in-state and out-of-state four-year institutions is robust across different models.

Now turning to treatment effects away from the eligibility threshold, Table 10 holds results for our implicit test of the bounded conditional independence assumption that underlies the analysis of these effects. The table lists point estimates and standard errors for the $\pi$ parameter in Equation 2, i.e., the relationship between college outcomes listed in the left-hand column of Table 10 and the running variable $E F C_{i c}-\bar{E}_{c}$ for Pell-ineligible students. With the small but statistically significant exception of out-of-state four-year enrollment, we find that the running variable is an insignificant component of college choice, conditional on students' $X_{i c}$.

Table 11 lists treatment effects away from the eligibility threshold for subsamples of students. Column (1) lists results for all students which are the same as those presented in Figures 4, 5, and 6, and estimates by gender and race are presented in Columns (2) through (5). Similar to results for all students, Pell eligibility has no significant treatment effect on college going below the threshold for these subsamples of students, and likewise, we find little meaningful impacts on students' chosen college sector below the Pell cut-off. The exception is for enrollment in a private four-year college, and this positive treatment effect below the threshold is concentrated among male and white students. Regression discontinuity results from Tables 5 and 8 indicate that marginal Pell eligibility leads males to sort into more selective colleges, in terms of the ACT scores of preceding classes. Table 11 finds no such treatment effect below the threshold, suggesting that males' sensitivity to Pell grants is very local with regards to colleges' ACT intake. In terms of the price of college, however, students below the Pell cut-off - particularly males and whites - attend colleges with higher tuition and fees, ${ }^{20}$ in contrast to null discontinuities at the threshold for all four subgroups (Table 5).

Perhaps the most intriguing results in Table 11 are those when the estimating sample is restricted to white students (Column (4)). White students below the threshold are more apt to enroll in private four-year institutions (by 1.3 percentage points, or 10 percent of the mean), and they attend institutions with higher ACT scores (by 0.5 - 0.7 percent of the mean), higher graduation rates (by 2.5 percent of the mean), and higher tuition and fees on the order of 15 - 16 cents per dol-

\footnotetext{
${ }^{20}$ Unreported regression kink estimates similarly find a change in the slope of out-of-state tuition with respect to white students' EFC of 17 cents per dollar of Pell.
} 
lar of Pell aid. Given high returns to college quality documented elsewhere, it is conceivable that whites' behavioral changes due to Pell eligibility will yield modest returns over a career. The fact that these findings do not extend to under-represented minorities is concerning, as is the broader argument that much less costly interventions have proven to be more effective in changing student behavior. 


\section{References}

Alchian, A. A., \& Allen, W. R. (1967). University Economics. Wadsworth Publishing Company.

Angrist, J., \& Rokkanen, M. (forthcoming). Wanna Get Away? RD Identification Away From the Cutoff. Journal of the American Statistical Association.

Avery, C., \& Hoxby, C. M. (2004). Do and should financial aid packages affect students' college choices. In C. M. Hoxby (Ed.) College Choices: The Economics of Where to Go, When to Go, and How to Pay for It. Chicago: University of Chicago Press.

Bettinger, E. (2004). How Financial Aid Affects Persistence. In C. M. Hoxby (Ed.) College Choices: The Economics of Where to Go, When to Go, and How to Pay for It. Chicago: University of Chicago Press.

Bettinger, E. P., Long, B. T., Oreopoulos, P., \& Sanbonmatsu, L. (2012). The Role of Application Assistance and Information in College Decisions: Results from the H\&R Block FAFSA Experiment. Quarterly Journal of Economics, 127(3), 1205 - 1242.

Bruce, D. J., \& Carruthers, C. K. (2014). Jackpot? The Impact of Lottery Scholarships on Enrollment in Tennessee. Journal of Urban Economics, 81, 30-44.

Card, D., Lee, D., Pei, Z., \& Weber, A. (2012). Nonlinear Policy Rules and Identification and Estimation of Causal Effects in a Generalized Regression Kink Design. Working Paper No. 18564, National Bureau of Economic Research, Cambridge, MA.

Cohodes, S., \& Goodman, J. (2014). Merit Aid, College Quality, and College Completion: Massachusetts' Adams Scholarship as an In-Kind Subsidy. American Economic Journal: Economic Policy, 6(4), 251-85.

Dale, S., \& Krueger, A. B. (2011). Estimating the Return to College Selectivity over the Career Using Administrative Earnings Data. Working Paper No. 14367, National Bureau of Economic Research, Cambridge, MA. 
Deming, D., \& Dynarski, S. (2010). Into College and Out of Poverty? Policies to Increase the Postsecondary Attainment of the Poor. In P. Levine, \& D. Zimmerman (Eds.) Targeting Investments in Children: Fighting Poverty When Resources Are Limited. University of Chicago Press.

Dynarski, S., \& Scott-Clayton, J. (2008). Complexity and Targeting in Federal Student Aid: A Quantitative Analysis. In J. M. Poterba (Ed.) Tax Policy and the Economy, Volume 22. Chicago: The University of Chicago Press.

Dynarski, S., Scott-Clayton, J., \& Wiederspan, M. (2013). Simplifying Tax Incentives and Aid for College: Progress and Prospects. Working Paper No. 18707, National Bureau of Economic Research, Cambridge, MA.

Dynarski, S., \& Scott-Clayton, J. E. (2006). The Cost of Complexity in Federal Student Aid: Lessons from Optimal Tax Theory and Behavioral Economics. National Tax Journal, 59(2), 319-356.

Dynarski, S., \& Wiederspan, M. (2012). Student Aid Simplification: Looking Back and Looking Ahead. National Tax Journal, 65(1), 211-234.

Goodman, J. (2008). Who Merits Financial Aid? Massachusetts' Adams Scholarship. Journal of Public Economics, 92, 2121-2131.

Goodman, J., Hurwitz, M., \& Smith, J. (2015). College access, initial college choice and degree completion. National Bureau of Economic Research Working Paper No. 20996.

Hansen, W. L. (1983). The Impact of Student Financial Aid on Access. In J. Froomkin (Ed.) The Crises in Higher Education. New York: Academy of Political Science.

Hoekstra, M. (2009). The Effect of Attending a Flagship State Univeristy on Earnings: A Regression Discontinuity Approach. Review of Economics and Statistics, 91, 717-724.

Hoxby, C., \& Turner, S. (2014). Expanding College Opportunities for Low-Income, HighAchieving Students. Stanford Institute for Economic Policy Research Discussion Paper No. $12-014$. 
Imbens, G., \& Kalyanaraman, K. (2012). Optimal Bandwidth Choice for the Regression Discontinuity Estimator. Review of Economic Studies, 20, 1-27.

Jacob, B., McCall, B., \& Stange, K. M. (2013). College as country club: Do colleges cater to students' preferences for consumption? National Bureau of Economic Research Working Paper No. 18745.

Kane, T. J. (1995). Rising Public College Tuition and College Entry: How Well Do Public Subsidies Promote Access to College? Working Paper No. 5164, National Bureau of Economic Research, Cambridge, MA.

Kane, T. J., \& Rouse, C. E. (1995). Labor-Market Returns to Two- and Four-Year College. American Economic Review, 85(3), 600 - 614.

Kline, P. (2011). Oaxaca-Blinder as a Reweighting Estimator. American Economic Review, 101(3), $532-537$.

Long, B. T. (2004). How have college decisions changed over time? An application of the conditional logistic choice model. Journal of Econometrics, 121, 271-296.

Lovenheim, M. F., \& Reynolds, C. L. (2012). The Effect of Housing Wealth on College Choice: Evidence from the Housing Boom. Working Paper No. 18075, National Bureau of Economic Research, Cambridge, MA.

Lovenheim, M. F., \& Reynolds, C. L. (2013). The Effect of Housing Wealth on College Choice: Evidence from the Housing Boom. Journal of Human Resources, 48(1), 1-35.

McCrary, J. (2008). Manipulation of the Running Variable in the Regression Discontinuity Design: A Density Test. Journal of Econometrics, 142, 698-714.

Reynolds, C. L. (2012). Where to Attend? Estimating the Effects of Beginning College at a Twoyear Institution. Economics of Education Review, 31(4), 345-362.

Rubin, R. B. (2011). The Pell and the Poor: A Regression-Discontinuity Analysis of On-Time College Enrollment. Research in Higher Education, 52(7), 675 - 692. 
Seftor, N. S., \& Turner, S. E. (2002). Back to School: Federal Student Aid Policy and Adult College Enrollment. Journal of Human Resources, 37(2), 336 - 352.

The College Board (1996). 1996 College-Bound Seniors: A Profile of SAT Program Test Takers. Tech. rep.

Turner, L. (2014). The Incidence of Financial Aid: Evidence from the Pell Grant Program. Working paper.

U.S. Department of Education (2007). Summary of Changes for the Application Processing System: 2008-2009. Washington, D.C: U.S. Department of Education, Federal Student Aid, (p. 6).

U.S. Department of Education (2012). 2011-2012 Federal Pell Grant Program End-ofYear Report. Office of Postsecondary Education. Retrieved March 7, 2014, from http://www2.ed.gov/finaid/prof/resources/data/pell-2011-12/pell-eoy-2011-12.pdf. 
TABLE 1: Summary statistics by college-going status and bandwidth

\begin{tabular}{|c|c|c|c|c|}
\hline \multirow[b]{3}{*}{ College-going? } & \multirow{2}{*}{\multicolumn{2}{|c|}{ Full samp }} & \multirow{2}{*}{\multicolumn{2}{|c|}{$\begin{array}{l}\text { (3) } \\
\text { Bandwidth-restricted sample }\end{array}$}} \\
\hline & & & & \\
\hline & No $(20.3 \%)$ & Yes $(79.7 \%)$ & No $(19.5 \%)$ & Yes $(80.5 \%)$ \\
\hline Pell eligible & $\begin{array}{c}0.721 \\
(0.449)\end{array}$ & $\begin{array}{c}0.437 \\
(0.496)\end{array}$ & $\begin{array}{c}0.644 \\
(0.479)\end{array}$ & $\begin{array}{c}0.583 \\
(0.493)\end{array}$ \\
\hline Potential Pell award (thousands) & $\begin{array}{c}3.079 \\
(2.175)\end{array}$ & $\begin{array}{c}1.660 \\
(2.100)\end{array}$ & $\begin{array}{c}1.414 \\
(1.280)\end{array}$ & $\begin{array}{c}1.225 \\
(1.248)\end{array}$ \\
\hline Mother has a college education & $\begin{array}{c}0.246 \\
(0.431)\end{array}$ & $\begin{array}{c}0.438 \\
(0.496)\end{array}$ & $\begin{array}{c}0.272 \\
(0.445)\end{array}$ & $\begin{array}{c}0.388 \\
(0.487)\end{array}$ \\
\hline Father has a college education & $\begin{array}{c}0.143 \\
(0.350)\end{array}$ & $\begin{array}{c}0.357 \\
(0.479)\end{array}$ & $\begin{array}{c}0.151 \\
(0.358)\end{array}$ & $\begin{array}{c}0.265 \\
(0.441)\end{array}$ \\
\hline Eligible for TN HOPE & $\begin{array}{c}0.066 \\
(0.249)\end{array}$ & $\begin{array}{c}0.413 \\
(0.492)\end{array}$ & $\begin{array}{c}0.101 \\
(0.302)\end{array}$ & $\begin{array}{c}0.409 \\
(0.492)\end{array}$ \\
\hline Eligible for TN ACCESS & $\begin{array}{c}0.005 \\
(0.070)\end{array}$ & $\begin{array}{c}0.01 \\
(0.102)\end{array}$ & $\begin{array}{c}0.004 \\
(0.061)\end{array}$ & $\begin{array}{l}0.01 \\
(0.097)\end{array}$ \\
\hline Eligible for TN GAM & $\begin{array}{c}0.003 \\
(0.058)\end{array}$ & $\begin{array}{c}0.045 \\
(0.207)\end{array}$ & $\begin{array}{c}0.002 \\
(0.047)\end{array}$ & $\begin{array}{c}0.025 \\
(0.155)\end{array}$ \\
\hline White, non-Hispanic & $\begin{array}{c}0.642 \\
(0.479)\end{array}$ & $\begin{array}{c}0.748 \\
(0.434)\end{array}$ & $\begin{array}{c}0.733 \\
(0.442)\end{array}$ & $\begin{array}{c}0.739 \\
(0.439)\end{array}$ \\
\hline Female & $\begin{array}{c}0.529 \\
(0.499)\end{array}$ & $\begin{array}{c}0.561 \\
(0.496)\end{array}$ & $\begin{array}{c}0.474 \\
(0.499)\end{array}$ & $\begin{array}{c}0.564 \\
(0.496)\end{array}$ \\
\hline Best ACT Composite Score & $\begin{array}{l}18.9 \\
(3.1)\end{array}$ & $\begin{array}{l}21.2 \\
(4.3)\end{array}$ & $\begin{array}{l}19.0 \\
(3.1)\end{array}$ & $\begin{array}{l}20.8 \\
(4.0)\end{array}$ \\
\hline First ACT Composite Score & $\begin{array}{l}18.1 \\
(2.9)\end{array}$ & $\begin{array}{l}20.1 \\
(4.2)\end{array}$ & $\begin{array}{l}18.3 \\
(2.9)\end{array}$ & $\begin{array}{l}19.7 \\
(4.0)\end{array}$ \\
\hline Self-reported high school GPA & $\begin{array}{c}3.074 \\
(0.451)\end{array}$ & $\begin{array}{c}3.244 \\
(0.516)\end{array}$ & $\begin{array}{c}3.074 \\
(0.458)\end{array}$ & $\begin{array}{c}3.224 \\
(0.520)\end{array}$ \\
\hline Number of ACT attempts & $\begin{array}{c}1.8 \\
(0.7)\end{array}$ & $\begin{array}{c}2.1 \\
(1.0)\end{array}$ & $\begin{array}{c}1.8 \\
(0.7)\end{array}$ & $\begin{array}{c}2.1 \\
(1.0)\end{array}$ \\
\hline $\mathrm{N}$ (students) & 28,470 & 112,046 & 6,852 & 28,340 \\
\hline
\end{tabular}

Notes: Authors' calculations. Source data describe four cohorts of Tennessee public high school graduates from the classes of 2006-2009. The bandwidth-restricted subsample includes students whose expected family contribution falls within $\$ 3,000$ (nominal) of the Pell threshold. 
TABLE 2: Summary statistics for enrollees, by bandwidth

\begin{tabular}{|c|c|c|}
\hline & $\begin{array}{l}\text { (1) } \\
\text { Full sample }\end{array}$ & $\begin{array}{l}\text { (2) } \\
\text { Bandwidth-restricted }\end{array}$ \\
\hline \multicolumn{3}{|l|}{ College sector outcomes } \\
\hline Enrolled in a public TN two-year college & $\begin{array}{c}0.334 \\
(0.472)\end{array}$ & $\begin{array}{c}0.374 \\
(0.484)\end{array}$ \\
\hline Enrolled in a public TN four-year college & $\begin{array}{c}0.461 \\
(0.498)\end{array}$ & $\begin{array}{c}0.442 \\
(0.497)\end{array}$ \\
\hline Enrolled in a public out-of-state two-year college & $\begin{array}{c}0.014 \\
(0.117)\end{array}$ & $\begin{array}{c}0.014 \\
(0.119)\end{array}$ \\
\hline Enrolled in a public out-of-state four-year college & $\begin{array}{c}0.047 \\
(0.212)\end{array}$ & $\begin{array}{l}0.038 \\
(0.191)\end{array}$ \\
\hline Enrolled in a private four-year college & $\begin{array}{c}0.137 \\
(0.344)\end{array}$ & $\begin{array}{c}0.127 \\
(0.333)\end{array}$ \\
\hline Enrolled in a private two-year college & $\begin{array}{c}0.007 \\
(0.082)\end{array}$ & $\begin{array}{c}0.005 \\
(0.068)\end{array}$ \\
\hline \multicolumn{3}{|l|}{ College quality outcomes } \\
\hline ACT Composite 25th Percentile Score (or SAT equivalent) & $\begin{array}{l}19.1 \\
(2.9)\end{array}$ & $\begin{array}{l}18.8 \\
(2.7)\end{array}$ \\
\hline ACT Composite 75th Percentile Score (or SAT equivalent) & $\begin{array}{l}24.3 \\
(3.2)\end{array}$ & $\begin{array}{l}24.0 \\
(3.1)\end{array}$ \\
\hline Instructional expenditures per FTE student (thousands) & $\begin{array}{c}7.054 \\
(6.155)\end{array}$ & $\begin{array}{c}6.638 \\
(5.812)\end{array}$ \\
\hline Student-to-faculty ratio & $\begin{array}{l}16.4 \\
(5.6)\end{array}$ & $\begin{array}{l}16.7 \\
(5.2)\end{array}$ \\
\hline Graduation rate, total cohort & $\begin{array}{l}35.0 \\
(20.1)\end{array}$ & $\begin{array}{c}33.0 \\
(19.3)\end{array}$ \\
\hline Published in-state tuition and fees (thousands) & $\begin{array}{c}6.501 \\
(6.080)\end{array}$ & $\begin{array}{c}6.146 \\
(5.774)\end{array}$ \\
\hline Published out-of-state tuition and fees (thousands) & $\begin{array}{l}14.631 \\
(4.873)\end{array}$ & $\begin{array}{l}14.129 \\
(4.681)\end{array}$ \\
\hline Tuition and fees conditional on student residency (thousands) & $\begin{array}{c}6.978 \\
(6.396)\end{array}$ & $\begin{array}{c}6.521 \\
(6.022)\end{array}$ \\
\hline "High research" or "Very high research" Carnegie class & $\begin{array}{c}0.341 \\
(0.474)\end{array}$ & $\begin{array}{c}0.306 \\
(0.461)\end{array}$ \\
\hline$N$ (students) & 112,046 & 28,340 \\
\hline
\end{tabular}




\section{Pell eligibility}

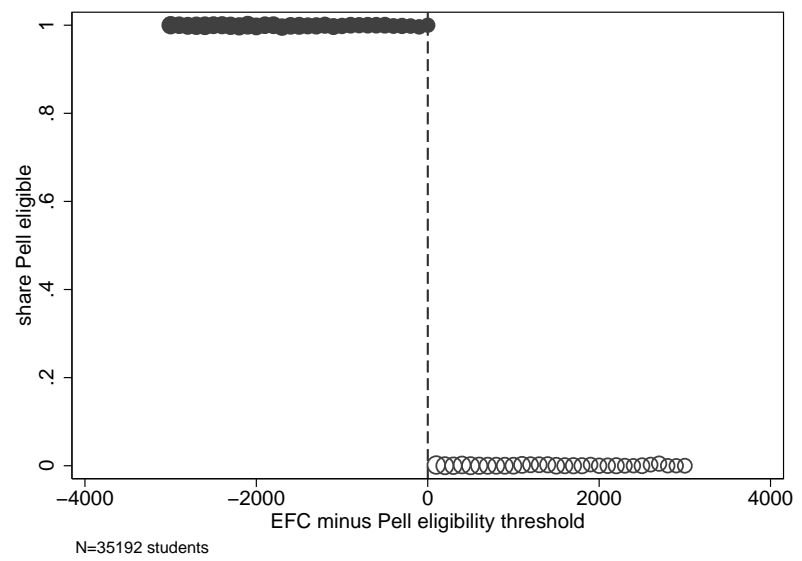

II. Full-time Pell award

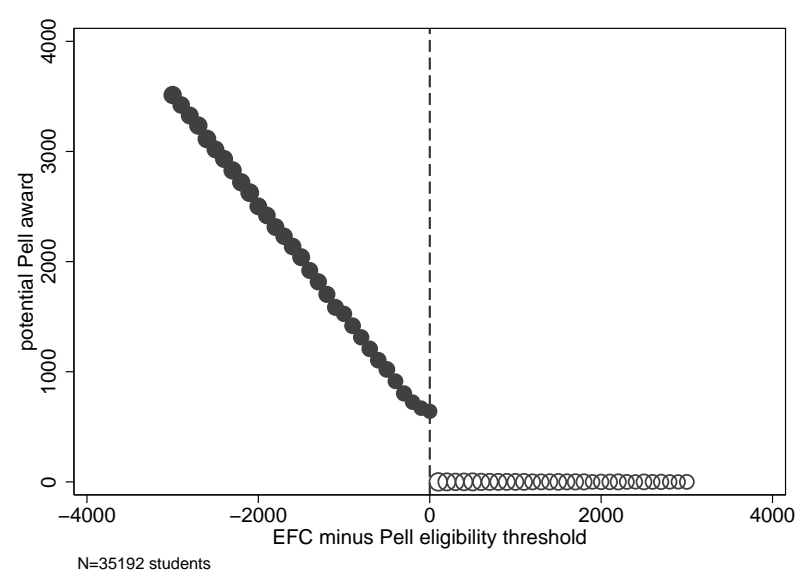

FIGURE 1: Pell eligibility (Panel I) and potential grant amounts (Panel II), by distance from EFC thresholds. Scatter points (dots) represent mean eligibility or grant by distance from Pell eligibility thresholds, weighted by the number of students in each $\$ 100 \mathrm{EFC}$ bin. 
TABLE 3: Falsification tests for discontinuities in observables and predicted outcomes

\begin{tabular}{lll}
\hline \hline & & \\
& $(1)$ & $(2)$ \\
& Coefficient & Robust St. Err. \\
\hline & & \\
Student characteristics & & \\
Mother has a college education & 0.001 & $(0.012)$ \\
Father has a college education & $-0.016^{* *}$ & $(0.007)$ \\
Eligible for TN HOPE & -0.015 & $(0.014)$ \\
Eligible for TN ACCESS & $-4.5 \mathrm{E}-04$ & $(0.002)$ \\
Eligible for TN GAM & 0.002 & $(0.003)$ \\
White, non-Hispanic & 0.007 & $(0.008)$ \\
Female & 0.004 & $(0.013)$ \\
Best ACT composite score & -0.046 & $(0.086)$ \\
First ACT composite score & -0.024 & $(0.095)$ \\
Self-reported high school GPA & 0.006 & $(0.009)$ \\
Number of ACT attempts & -0.006 & $(0.018)$ \\
& & \\
Predicted college outcomes & & \\
Predicted: any college enrollment & -0.006 & $(0.007)$ \\
Predicted: two-year in-state public enrollment & 0.002 & $(0.003)$ \\
Predicted: four-year in-state enrollment & -0.007 & $(0.006)$ \\
Predicted: two-year out-of-state public enrollment & $8.0 \mathrm{E}-05$ & $(2.6 \mathrm{E}-04)$ \\
Predicted: four-year out-of-state public enrollment & $2.5 \mathrm{E}-04$ & $(0.001)$ \\
Predicted: private four-year enrollment & -0.001 & $(0.002)$ \\
Predicted: private two-year enrollment & $1.0 \mathrm{E}-05$ & $(1.6 \mathrm{E}-04)$ \\
\hline \hline
\end{tabular}

Notes: $N=35,192$ students. The table reports estimates of $\beta_{1}$ from Equation 1, applied to student observable variables (top panel) or predictions of college enrollment outcomes $\left(\hat{Y}_{i}\right.$, bottom panel) based on regressions of $Y_{i}$ against these same variables. Robust standard errors, clustered by $\$ 100 \mathrm{EFC}$ bin, are in parentheses next to each coefficient.

$* p<0.1 ; * * p<0.05 ; * * * p<0.01$ 


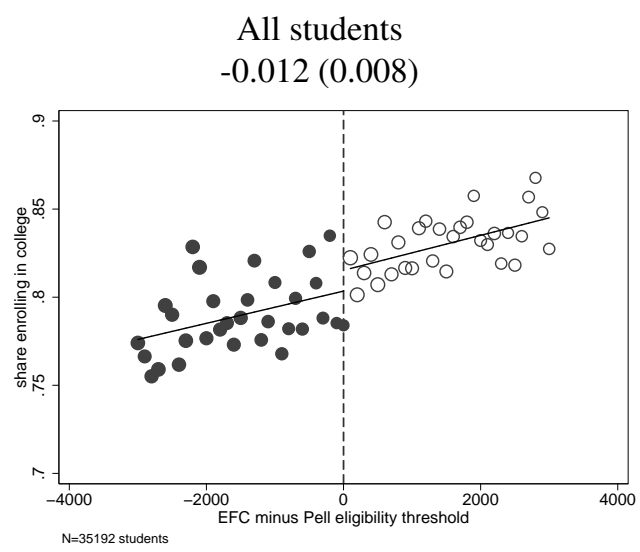

Male students

$-0.012(0.014)$

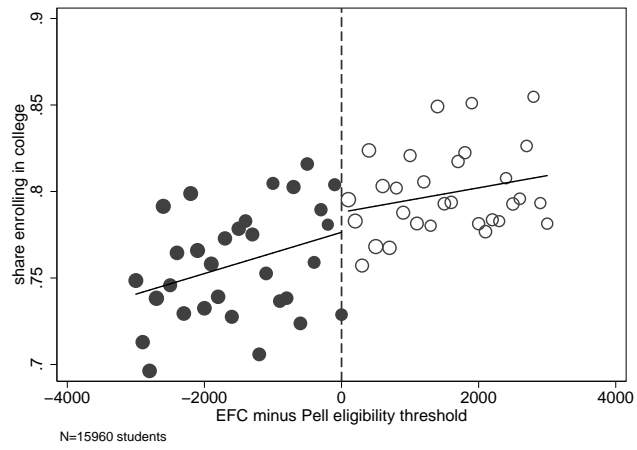

Female students

$-0.012(0.012)$

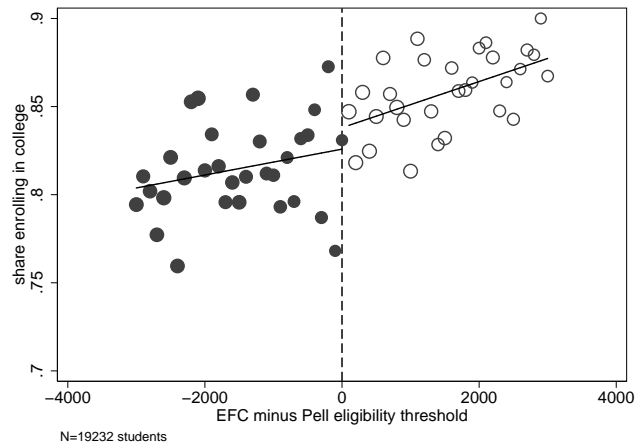

White students

$-0.016^{*}(0.009)$

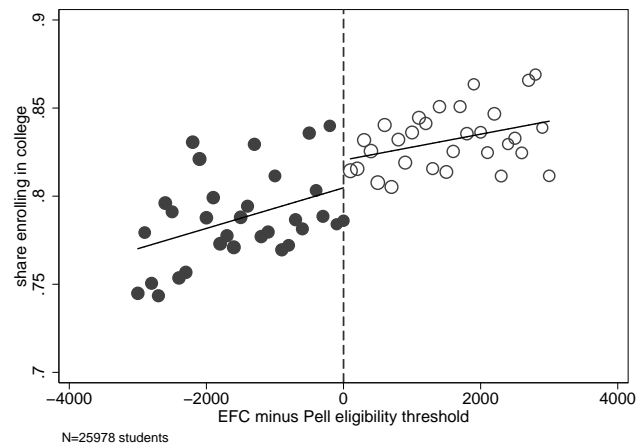

Black students $0.008(0.017)$

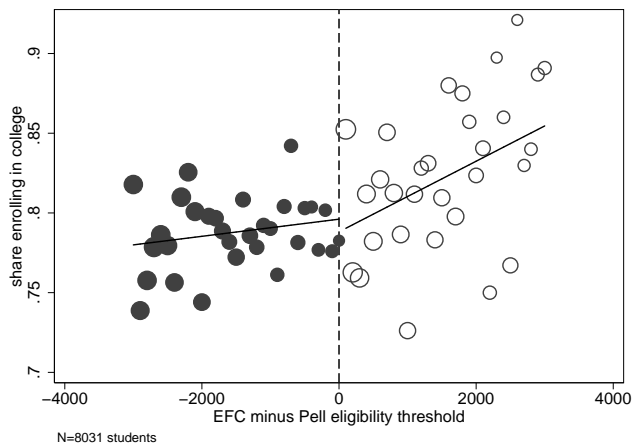

FIGURE 2: Regression discontinuity results for any college enrollment. Scatter points (dots) represent mean college enrollment by distance from Pell eligibility thresholds, weighted by the number of students in each $\$ 100 \mathrm{EFC}$ bin. Lines fit predictions from Equation 1. Point estimates for $\beta_{1}$ are reported below figure headings, with robust standard errors in parentheses.

$* p<0.1 ; * * p<0.05 ; * * * p<0.01$ 
TABLE 4: Regression discontinuity estimates (Equation 1) for choice of college sector

\begin{tabular}{|c|c|c|c|c|c|}
\hline & $\begin{array}{l}\text { (1) } \\
\text { All students }\end{array}$ & $\begin{array}{l}\text { (2) } \\
\text { Male students }\end{array}$ & $\begin{array}{l}\text { (3) } \\
\text { Female students }\end{array}$ & $\begin{array}{l}\text { (4) } \\
\text { White students }\end{array}$ & $\begin{array}{l}\text { (5) } \\
\text { Black students }\end{array}$ \\
\hline Enrolled in a public TN two-year college & $\begin{array}{c}0.001 \\
(0.015)\end{array}$ & $\begin{array}{l}-0.025 \\
(0.020)\end{array}$ & $\begin{array}{c}0.022 \\
(0.017)\end{array}$ & $\begin{array}{c}0.001 \\
(0.017)\end{array}$ & $\begin{array}{c}0.021 \\
(0.022)\end{array}$ \\
\hline Enrolled in a public TN four-year college & $\begin{array}{l}-0.008 \\
(0.016)\end{array}$ & $\begin{array}{c}0.017 \\
(0.020)\end{array}$ & $\begin{array}{l}-0.029 * \\
(0.017)\end{array}$ & $\begin{array}{l}-0.005 \\
(0.015)\end{array}$ & $\begin{array}{l}-0.022 \\
(0.030)\end{array}$ \\
\hline Enrolled in a public out-of-state two-year college & $\begin{array}{c}0.002 \\
(0.002)\end{array}$ & $\begin{array}{l}-0.001 \\
(0.004)\end{array}$ & $\begin{array}{c}0.004 \\
(0.003)\end{array}$ & $\begin{array}{c}0.004 \\
(0.003)\end{array}$ & $\begin{array}{l}-0.007 \\
(0.005)\end{array}$ \\
\hline Enrolled in a public out-of-state four-year college & $\begin{array}{c}0.003 \\
(0.005)\end{array}$ & $\begin{array}{l}-0.007 \\
(0.009)\end{array}$ & $\begin{array}{l}0.011^{*} \\
(0.006)\end{array}$ & $\begin{array}{c}0.005 \\
(0.006)\end{array}$ & $\begin{array}{l}-0.003 \\
(0.012)\end{array}$ \\
\hline Enrolled in a private four-year college & $\begin{array}{c}0.001 \\
(0.007)\end{array}$ & $\begin{array}{c}0.013 \\
(0.010)\end{array}$ & $\begin{array}{l}-0.008 \\
(0.010)\end{array}$ & $\begin{array}{l}-0.007 \\
(0.008)\end{array}$ & $\begin{array}{c}0.009 \\
(0.017)\end{array}$ \\
\hline Enrolled in a private two-year college & $\begin{array}{c}0.002 \\
(0.001)\end{array}$ & $\begin{array}{l}0.004 * \\
(0.002)\end{array}$ & $\begin{array}{l}1.5 \mathrm{E}-04 \\
(0.002)\end{array}$ & $\begin{array}{c}0.002 \\
(0.001)\end{array}$ & $\begin{array}{c}0.001 \\
(0.005)\end{array}$ \\
\hline$N$ (students ) & 28,340 & 12,359 & 15,981 & 20,955 & 6,388 \\
\hline
\end{tabular}

Notes: The table reports estimates of $\beta_{1}$ from Equation 1, applied to mutually exclusive and exhaustive college sector outcomes. Robust standard errors, clustered by $\$ 100 \mathrm{EFC}$ bin, are in parentheses next to each coefficient.

$* p<0.1 ; * * p<0.05 ; * * * p<0.01$ 
TN two-year public $0.001(0.015)$

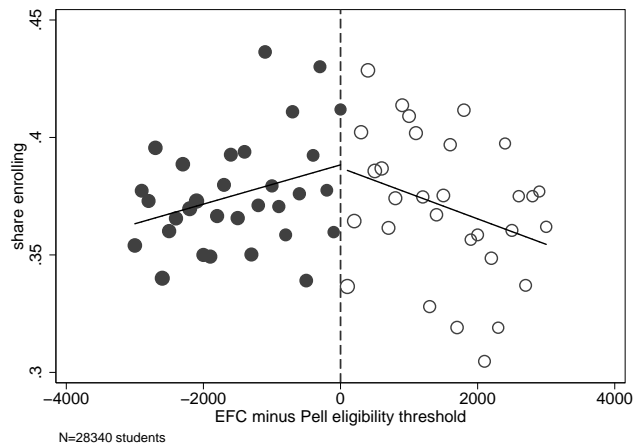

Out-of-state two-year public $0.002(0.002)$

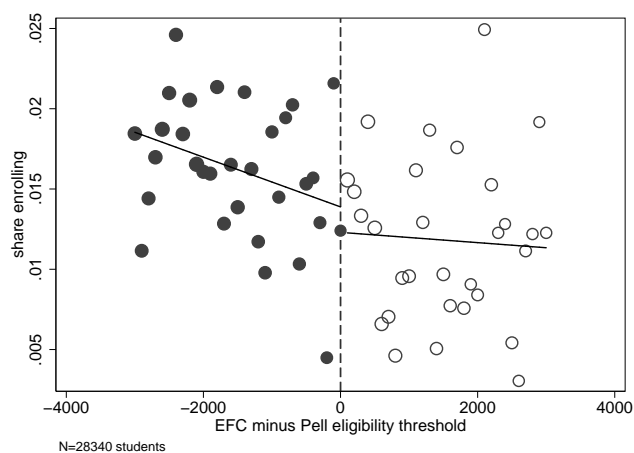

Private four-year 0.001 (0.007)

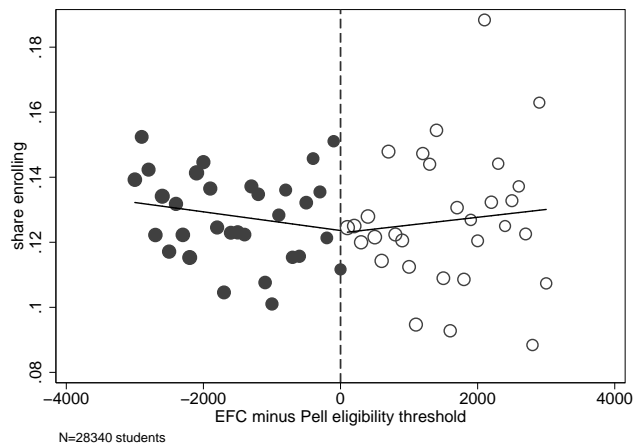

$\mathrm{TN}$ four-year public $-0.008(0.016)$

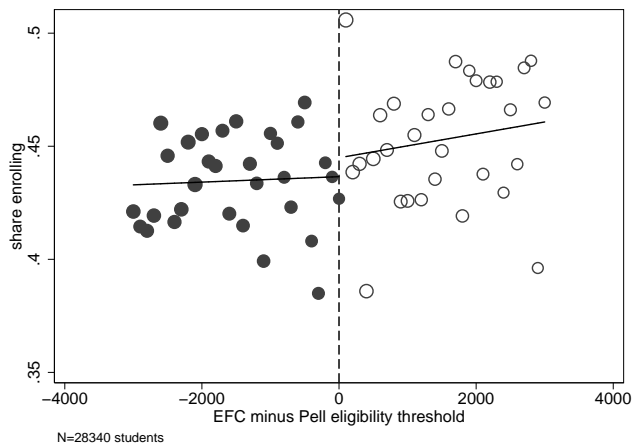

Out-of-state four-year public $0.003(0.005)$

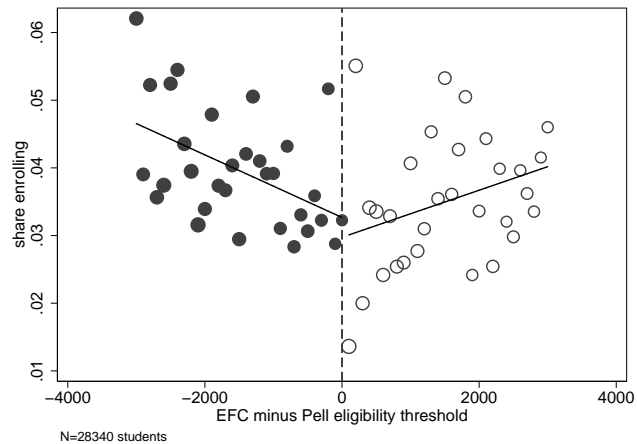

Private two-year

$0.002(0.001)$

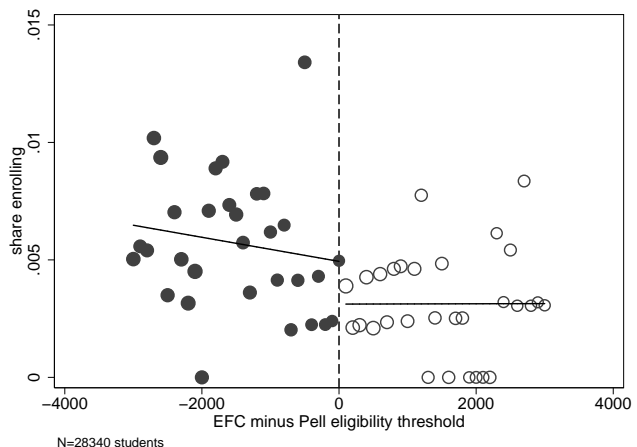

FIGURE 3: Regression discontinuity results for choice of college sector. Scatter points (dots) represent college sector outcomes by distance from Pell eligibility thresholds, weighted by the number of students in each $\$ 100 \mathrm{EFC}$ bin. Lines fit predictions from Equation 1. Point estimates for $\beta_{1}$ are reported below figure headings, with robust standard errors in parentheses.

$* p<0.1 ; * * p<0.05 ; * * * p<0.01$ 
TABLE 5: Regression discontinuity estimates (Equation 1) for quality of college chosen

\begin{tabular}{|c|c|c|c|c|c|}
\hline & $\begin{array}{l}\text { (1) } \\
\text { All students }\end{array}$ & $\begin{array}{l}(2) \\
\text { Male students }\end{array}$ & $\begin{array}{l}\text { (3) } \\
\text { Female students }\end{array}$ & $\begin{array}{l}\text { (4) } \\
\text { White students }\end{array}$ & $\begin{array}{l}\text { (5) } \\
\text { Black students }\end{array}$ \\
\hline ACT 25th percentile (or SAT equivalent) & $\begin{array}{c}0.114 \\
(0.068)\end{array}$ & $\begin{array}{l}0.217 * * \\
(0.103)\end{array}$ & $\begin{array}{c}0.031 \\
(0.085)\end{array}$ & $\begin{array}{c}0.083 \\
(0.079)\end{array}$ & $\begin{array}{c}0.028 \\
(0.206)\end{array}$ \\
\hline ACT 75th percentile (or SAT equivalent) & $\begin{array}{c}0.115 \\
(0.073)\end{array}$ & $\begin{array}{l}0.314 * * * \\
(0.113)\end{array}$ & $\begin{array}{l}-0.043 \\
(0.105)\end{array}$ & $\begin{array}{c}0.091 \\
(0.086)\end{array}$ & $\begin{array}{c}0.031 \\
(0.211)\end{array}$ \\
\hline Instructional expenditures per FTE student & $\begin{array}{c}21.4 \\
(123.9)\end{array}$ & $\begin{array}{c}118.7 \\
(182.5)\end{array}$ & $\begin{array}{c}-54.5 \\
(190.3)\end{array}$ & $\begin{array}{c}69.1 \\
(137.8)\end{array}$ & $\begin{array}{l}-556.7 \\
(466.3)\end{array}$ \\
\hline Student-to-faculty ratio & $\begin{array}{l}-0.224 \\
(0.135)\end{array}$ & $\begin{array}{l}-0.355^{*} \\
(0.195)\end{array}$ & $\begin{array}{l}-0.123 \\
(0.153)\end{array}$ & $\begin{array}{l}-0.208 \\
(0.143)\end{array}$ & $\begin{array}{l}-0.109 \\
(0.261)\end{array}$ \\
\hline Graduation rate & $\begin{array}{c}0.814 \\
(0.530)\end{array}$ & $\begin{array}{c}1.109 \\
(0.829)\end{array}$ & $\begin{array}{c}0.575 \\
(0.617)\end{array}$ & $\begin{array}{c}0.614 \\
(0.621)\end{array}$ & $\begin{array}{l}-0.102 \\
(1.194)\end{array}$ \\
\hline In-state tuition and fees & $\begin{array}{c}162.1 \\
(135.7)\end{array}$ & $\begin{array}{c}246.5 \\
(209.3)\end{array}$ & $\begin{array}{c}100.2 \\
(185.1)\end{array}$ & $\begin{array}{c}78.7 \\
(126.3)\end{array}$ & $\begin{array}{c}-7.2 \\
(358.9)\end{array}$ \\
\hline Out-of-state tuition and fees & $\begin{array}{l}149.5 \\
(134.6)\end{array}$ & $\begin{array}{c}260.7 \\
(184.5)\end{array}$ & $\begin{array}{c}61.5 \\
(156.6)\end{array}$ & $\begin{array}{c}148.0 \\
(129.3)\end{array}$ & $\begin{array}{l}-202.4 \\
(332.5)\end{array}$ \\
\hline Tuition and fees, dependent on students' residency & $\begin{array}{c}217.3 \\
(140.1)\end{array}$ & $\begin{array}{l}200.0 \\
(218.0)\end{array}$ & $\begin{array}{l}234.0 \\
(207.8)\end{array}$ & $\begin{array}{c}160.6 \\
(139.8)\end{array}$ & $\begin{array}{c}-54.3 \\
(366.2)\end{array}$ \\
\hline "High research" or "Very high research" Carnegie class & $\begin{array}{c}0.007 \\
(0.014)\end{array}$ & $\begin{array}{c}0.009 \\
(0.019)\end{array}$ & $\begin{array}{c}0.005 \\
(0.018)\end{array}$ & $\begin{array}{c}0.010 \\
(0.014)\end{array}$ & $\begin{array}{l}-0.044 \\
(0.027)\end{array}$ \\
\hline$N$ (students ) & 24,653 & 10,675 & 13,978 & 18,314 & 5,429 \\
\hline
\end{tabular}

Notes: The table reports estimates of $\beta_{1}$ from Equation 1, applied to quality measures of students' college choice. Robust standard errors, clustered by $\$ 100 \mathrm{EFC}$ bin, are in parentheses next to each coefficient.

$* p<0.1 ; * *<0.05 ; * * * p<0.01$ 
Any college enrollment

$-0.003(0.006)$

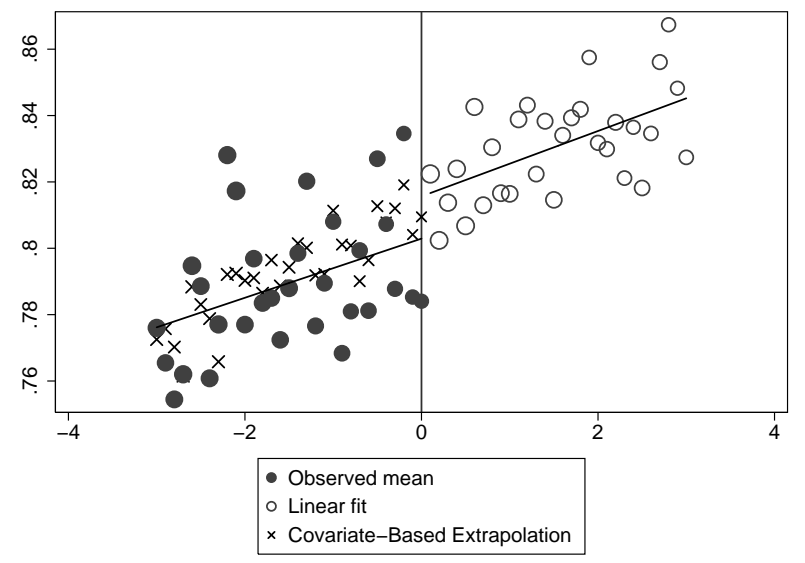

FIGURE 4: $N=35,073$ high school graduates. Treatment effect estimates for any college enrollment below the eligibility threshold. Scatter points (dots) represent mean college enrollment by distance from Pell eligibility thresholds, weighted by the number of students in each $\$ 100 \mathrm{EFC}$ bin. X-markers represent extrapolated college enrollment as predicted by a regression of outcomes against student observables above the eligibility threshold. Lines fit predictions from Equation 1. Point estimates for treatment effects below the threshold are reported below the figure heading, with standard errors in parentheses.

$* p<0.1 ; * * p<0.05 ; * * * p<0.01$ 
TN two-year public

$-0.004(0.008)$

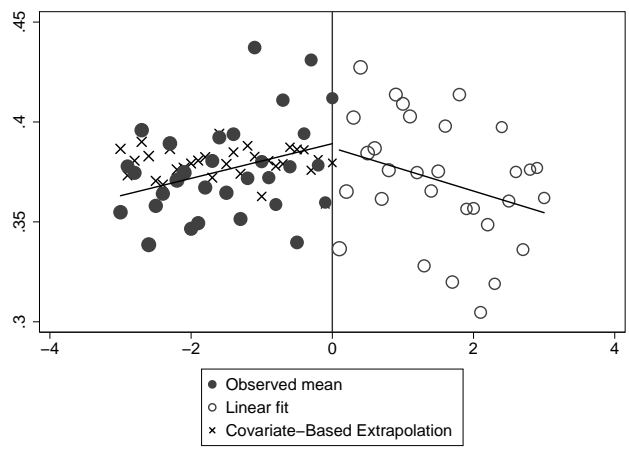

Out-of-state two-year public $-0.001(0.002)$

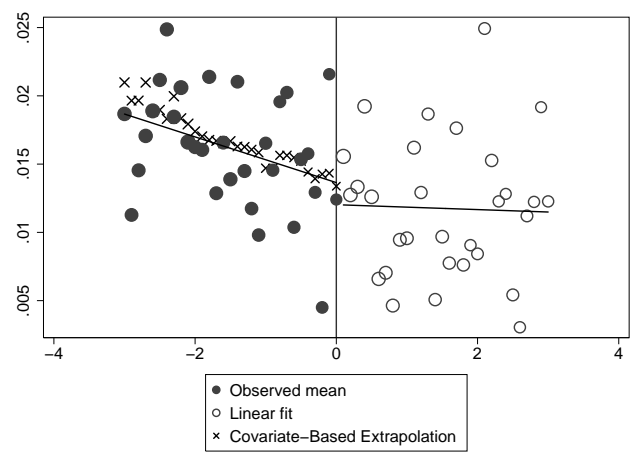

Private four-year

$0.011 *(0.006)$

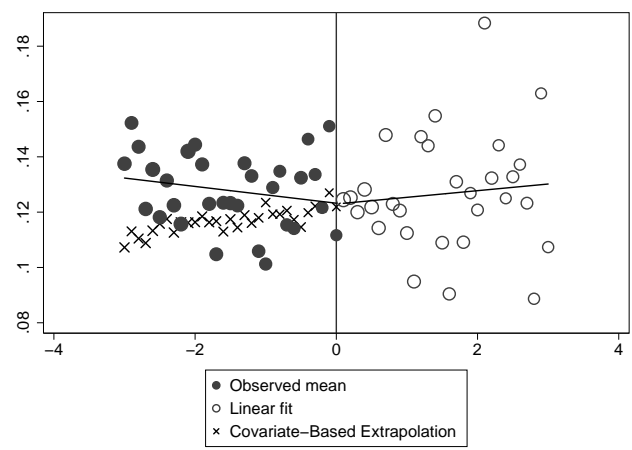

$\mathrm{TN}$ four-year public

$-0.002(0.009)$

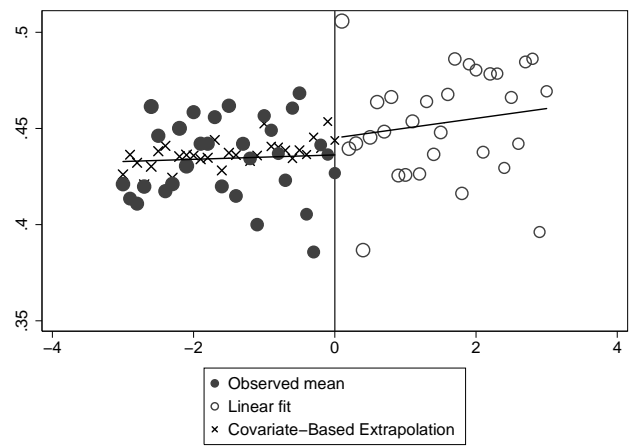

Out-of-state four-year public -0.005 (0.004)

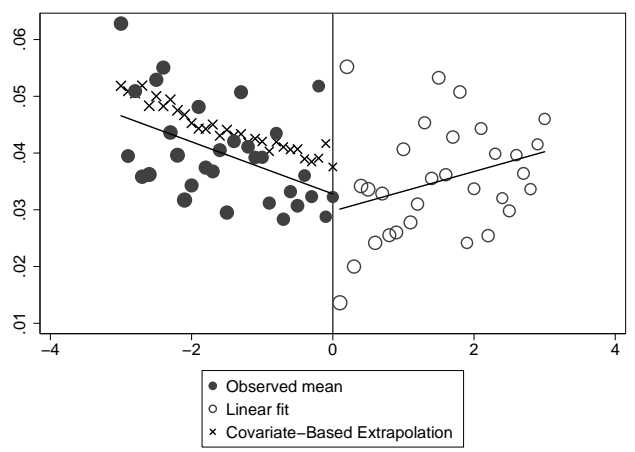

Private two-year

2.3E-04 (0.001)

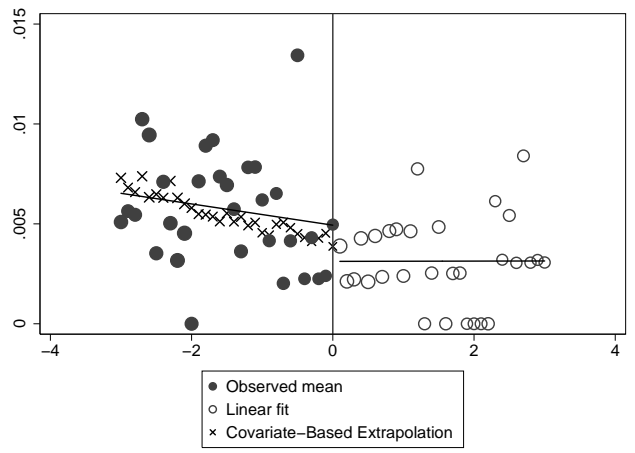

FIGURE 5: $N=28,250$ college-going students. Treatment effect estimates for college sector below the eligibility threshold. Scatter points (dots) represent college sector outcomes by distance from Pell eligibility thresholds, weighted by the number of students in each $\$ 100 \mathrm{EFC}$ bin. X-markers represent extrapolated college enrollment outcomes as predicted by a regression of outcomes against student observables above the eligibility threshold. Lines fit predictions from Equation 1. Point estimates for treatment effects below the threshold are reported below figure headings, with standard errors in parentheses.

$* p<0.1$; ** $p<0.05$; *** $p<0.01$ 
ACT 25th percentile

$0.074(0.046)$

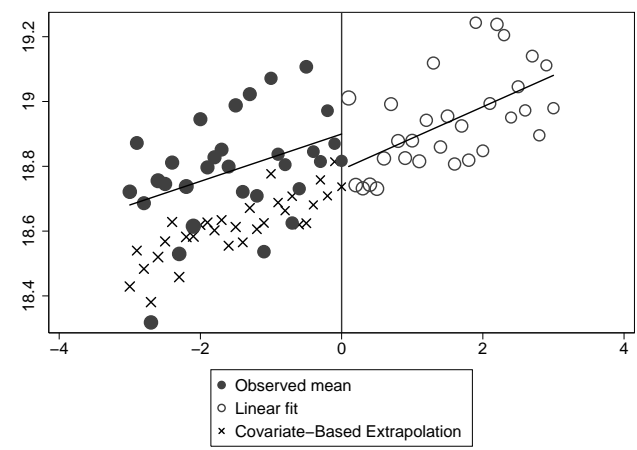

In-state published tuition

261.1** (106.8)

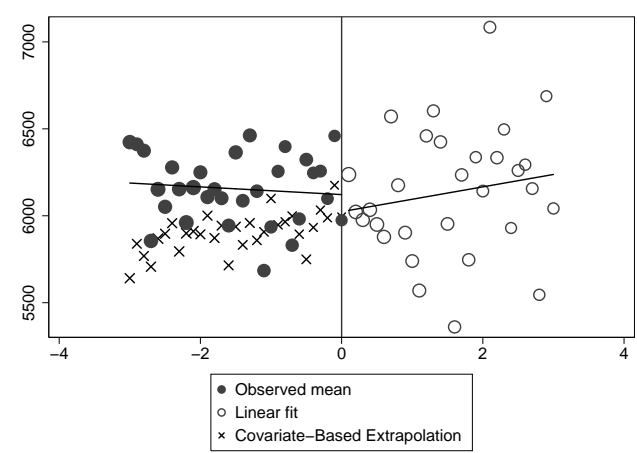

Tuition and fees dependent on student residency 213.6* (111.6)

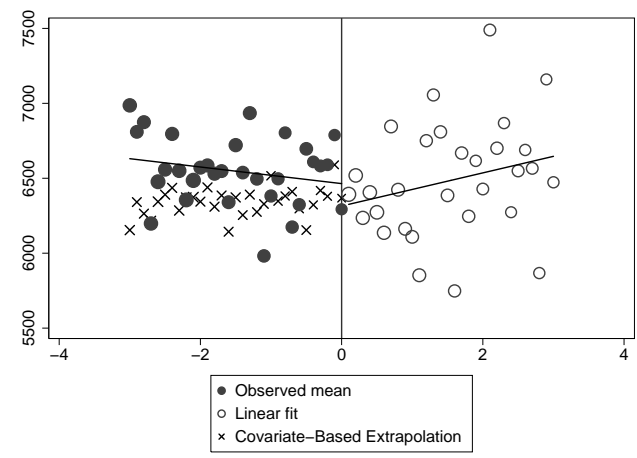

ACT 75th percentile $0.068(0.053)$

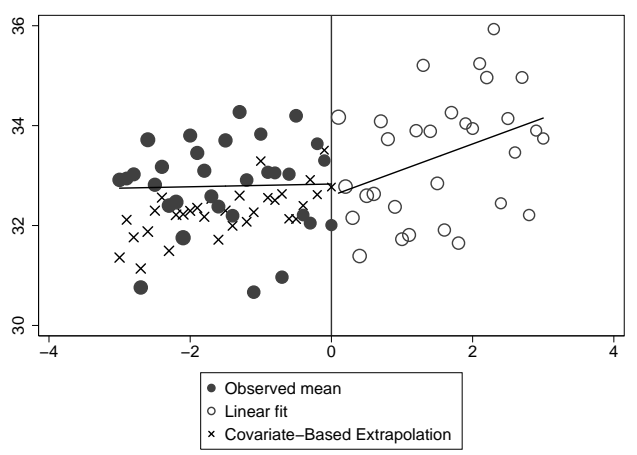

Out-of-state published tuition $299.3 * * *(75.7)$

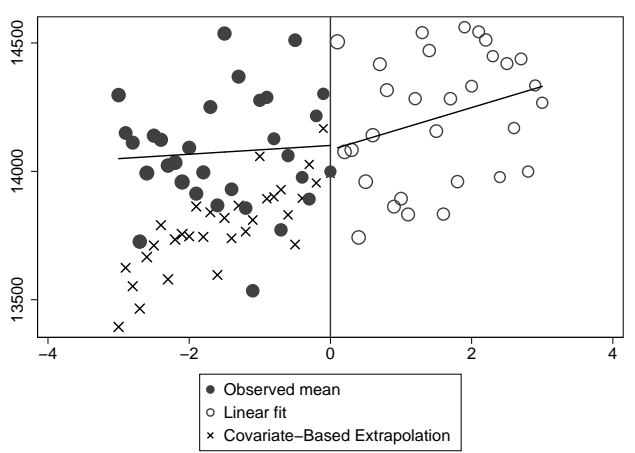

Graduation rate

$0.537 *(0.301)$

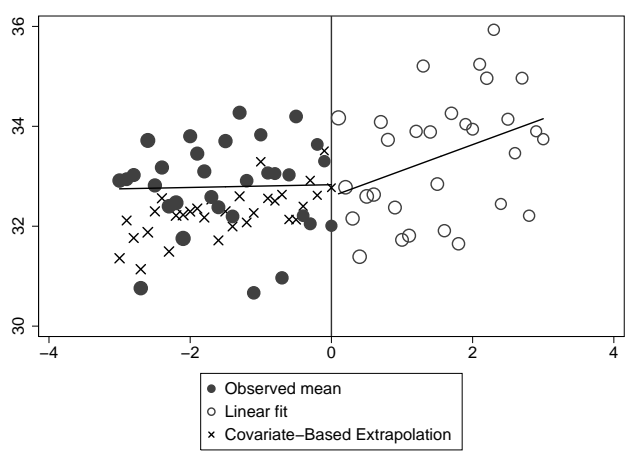

FIGURE 6: $N=28,250$ college-going students. Treatment effect estimates for college quality below the eligibility threshold. Scatter points (dots) represent college quality means by distance from Pell eligibility thresholds, weighted by the number of students in each $\$ 100 \mathrm{EFC}$ bin. X-markers represent extrapolated quality outcomes as predicted by a regression of quality measures against student observables above the eligibility threshold. Lines fit predictions from Equation 1. Point estimates for treatment effects below the threshold are reported below figure headings, with standard errors in parentheses.

$* p<0.1 ; * * p<0.05 ; * * * p<0.01$ 
TABLE 6: Regression discontinuity specification checks for any college enrollment, by gender and race

\begin{tabular}{llllll}
\hline \hline & & & & & \\
& $(1)$ & $(2)$ & $(3)$ & $(4)$ & $(5)$ \\
& All students & Male students & Female students & White students & Black students \\
\hline \multirow{2}{*}{ A. Baseline estimates } & -0.012 & -0.012 & -0.012 & $-0.016^{*}$ & 0.008 \\
& $(0.008)$ & $(0.014)$ & $(0.012)$ & $(0.009)$ & $(0.017)$ \\
B. With covariates & -0.006 & 0.001 & $-0.012^{*}$ & -0.005 & 0.002 \\
& $(0.004)$ & $(0.007)$ & $(0.006)$ & $(0.004)$ & $(0.011)$ \\
C. Narrow bandwidth $(1,500)$ & -0.014 & -0.007 & -0.021 & -0.017 & -0.007 \\
& $(0.011)$ & $(0.019)$ & $(0.019)$ & $(0.012)$ & $(0.023)$ \\
D. Optimal bandwidth & -0.011 & -0.008 & -0.018 & -0.013 & -0.003 \\
& $(0.010)$ & $(0.016)$ & $(0.016)$ & $(0.011)$ & $(0.020)$ \\
& {$[\$ 1,742]$} & {$[\$ 2,122]$} & {$[\$ 1,905]$} & {$[\$ 1,903]$} & {$[\$ 2,331]$} \\
E. \$500 EFC bins & -0.011 & -0.015 & -0.008 & $-0.017 *$ & 0.016 \\
& $(0.008)$ & $(0.014)$ & $(0.012)$ & $(0.009)$ & $(0.018)$ \\
F. Quadratic & -0.012 & -0.012 & -0.013 & $-0.016 *$ & 0.008 \\
& $(0.008)$ & $(0.014)$ & $(0.012)$ & $(0.009)$ & $(0.017)$ \\
$N$ (thousands) & $17.7-35.1$ & $8.0-16.0$ & $9.7-19.2$ & $13.5-26.0$ & $3.7-8.0$ \\
\hline \hline
\end{tabular}

Notes: The table reports estimates of $\beta_{1}$ from Equation 1, applied to the binary incidence of any college enrollment. Row A displays results from our baseline specification, also found in Figure 2. Row B illustrates results when covariates (cohort fixed effects and $X_{i}$ variables listed in Table 1) are included in Equation 1. Row C lists results when the bandwidth around the Pell eligibility threshold is narrowed from $\$ 3,000$ to $\$ 1,500$. Row D lists results under the optimal bandwidth for each outcome and subsample (Imbens \& Kalyanaraman, 2012). Row E lists results when we aggregate the EFC running variable to $\$ 500$ bins rather than $\$ 100$ bins. Row $F$ lists results when a quadratic rather than a linear function is used for $E F C_{i c}-\bar{E}_{c}$, the gap between $i$ 's EFC and that cohort's Pell eligibility threshold. Robust standard errors, clustered by $\$ 100 \mathrm{EFC}$ bin, are in parentheses under each coefficient. Optimal bandwidths are in brackets below standard errors in Row D.

$* p<0.1 ; * * p<0.05 ; * * * p<0.01$ 
I. RD estimate for any college enrollment, by bandwidth

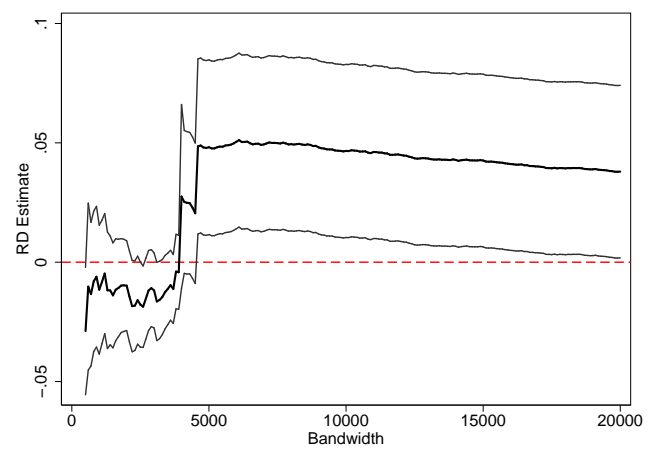

II. Any college enrollment, $\$ 5,500$ bandwidth $0.048 * * *(0.019)$

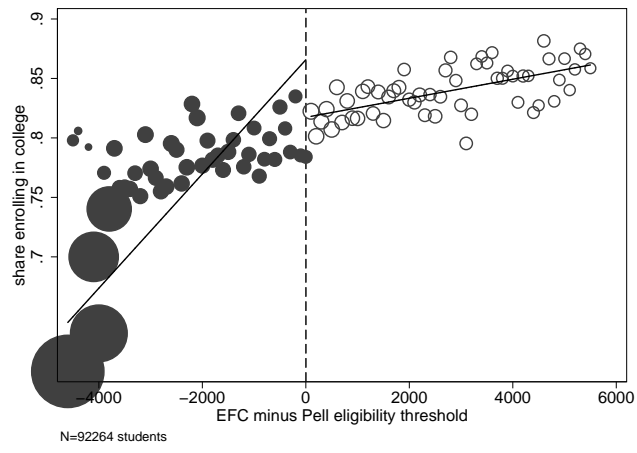

FIGURE 7: Sensitivity of regression discontinuity results to bandwidth. Panel I: RD treatment effect estimates and confidence intervals for any college enrollment, by bandwidth. Panel II: Scatter points (dots) represent mean college enrollment by distance from Pell eligibility thresholds, weighted by the number of students in each $\$ 100$ EFC bin. Lines fit predictions from Equation 1. Point estimates for treatment effects below the threshold are reported below figure headings, with standard errors in parentheses.

$* p<0.1 ; * * p<0.05 ; * * * p<0.01$ 
TABLE 7: Regression discontinuity specification checks for college sector and college quality, all students

\begin{tabular}{|c|c|c|c|c|c|c|c|}
\hline & $\begin{array}{c}(1) \\
\text { Baseline } \\
\end{array}$ & $\begin{array}{c}\text { (2) } \\
\text { All HS } \\
\text { graduates }\end{array}$ & $\begin{array}{c}(3) \\
\text { With } \\
\text { covariates }\end{array}$ & $\begin{array}{c}(4) \\
\text { Narrow } \\
\text { BW } \\
\end{array}$ & $\begin{array}{c}(5) \\
\text { Optimal } \\
\text { BW }\end{array}$ & $\begin{array}{c}(6) \\
\$ 500 \\
\text { EFC bins } \\
\end{array}$ & $\begin{array}{c}\text { (7) } \\
\text { Quadratic }\end{array}$ \\
\hline Enrolled in a public $\mathrm{TN}$ two-year college & $\begin{array}{c}0.001 \\
(0.015)\end{array}$ & $\begin{array}{l}-0.004 \\
(0.012)\end{array}$ & $\begin{array}{c}0.002 \\
(0.013)\end{array}$ & $\begin{array}{c}0.007 \\
(0.022)\end{array}$ & $\begin{array}{c}-0.002 \\
(0.018) \\
{[\$ 2,418]}\end{array}$ & $\begin{array}{l}-0.005 \\
(0.015)\end{array}$ & $\begin{array}{c}0.001 \\
(0.015)\end{array}$ \\
\hline Enrolled in a public TN four-year college & $\begin{array}{l}-0.008 \\
(0.016)\end{array}$ & $\begin{array}{l}-0.012 \\
(0.014)\end{array}$ & $\begin{array}{l}-0.009 \\
(0.014)\end{array}$ & $\begin{array}{l}-0.024 \\
(0.023)\end{array}$ & $\begin{array}{c}-0.011 \\
(0.018) \\
{[\$ 2,491]}\end{array}$ & $\begin{array}{l}-0.007 \\
(0.016)\end{array}$ & $\begin{array}{l}-0.009 \\
(0.015)\end{array}$ \\
\hline Enrolled in a public out-of-state two-year college & $\begin{array}{c}0.002 \\
(0.002)\end{array}$ & $\begin{array}{c}0.001 \\
(0.002)\end{array}$ & $\begin{array}{c}0.002 \\
(0.002)\end{array}$ & $\begin{array}{l}-0.001 \\
(0.003)\end{array}$ & $\begin{array}{c}0.001 \\
(0.002) \\
{[\$ 6,269]}\end{array}$ & $\begin{array}{c}0.002 \\
(0.002)\end{array}$ & $\begin{array}{c}0.002 \\
(0.002)\end{array}$ \\
\hline Enrolled in a public out-of-state four-year college & $\begin{array}{c}0.003 \\
(0.005)\end{array}$ & $\begin{array}{c}0.002 \\
(0.004)\end{array}$ & $\begin{array}{c}0.003 \\
(0.005)\end{array}$ & $\begin{array}{c}0.009 \\
(0.009)\end{array}$ & $\begin{array}{c}0.004 \\
(0.005) \\
{[\$ 3,764]}\end{array}$ & $\begin{array}{c}0.004 \\
(0.006)\end{array}$ & $\begin{array}{c}0.003 \\
(0.005)\end{array}$ \\
\hline Enrolled in a private four-year college & $\begin{array}{c}0.001 \\
(0.007)\end{array}$ & $\begin{array}{l}-0.001 \\
(0.006)\end{array}$ & $\begin{array}{c}0.001 \\
(0.007)\end{array}$ & $\begin{array}{c}0.009 \\
(0.008)\end{array}$ & $\begin{array}{c}0.003 \\
(0.005) \\
{[\$ 8,683]}\end{array}$ & $\begin{array}{c}0.003 \\
(0.007)\end{array}$ & $\begin{array}{c}0.001 \\
(0.007)\end{array}$ \\
\hline Enrolled in a private two-year college & $\begin{array}{c}0.002 \\
(0.001)\end{array}$ & $\begin{array}{c}0.001 \\
(0.001)\end{array}$ & $\begin{array}{c}0.002 \\
(0.001)\end{array}$ & $\begin{array}{c}0.001 \\
(0.002)\end{array}$ & $\begin{array}{c}0.002 \\
(0.001) \\
{[\$ 2,823]}\end{array}$ & $\begin{array}{c}0.002^{*} \\
(0.001)\end{array}$ & $\begin{array}{c}0.002 \\
(0.001)\end{array}$ \\
\hline ACT 25th percentile (or SAT equivalent) & $\begin{array}{c}0.114 \\
(0.068)\end{array}$ & $\begin{array}{c}0.114 \\
(0.068)\end{array}$ & $\begin{array}{c}0.095^{*} \\
(0.054)\end{array}$ & $\begin{array}{c}0.076 \\
(0.094)\end{array}$ & $\begin{array}{c}0.08 \\
(0.080) \\
{[\$ 2,117]}\end{array}$ & $\begin{array}{c}0.120^{*} \\
(0.063)\end{array}$ & $\begin{array}{c}0.113 \\
(0.068)\end{array}$ \\
\hline ACT 75th percentile (or SAT equivalent) & $\begin{array}{c}0.115 \\
(0.073)\end{array}$ & $\begin{array}{c}0.115 \\
(0.073)\end{array}$ & $\begin{array}{c}0.094 \\
(0.059)\end{array}$ & $\begin{array}{c}0.102 \\
(0.105)\end{array}$ & $\begin{array}{c}0.155^{*} \\
(0.087) \\
{[\$ 2,350]}\end{array}$ & $\begin{array}{c}0.127^{*} \\
(0.067)\end{array}$ & $\begin{array}{c}0.114 \\
(0.072)\end{array}$ \\
\hline Instructional expenditures per FTE student & $\begin{array}{c}21.4 \\
(123.9)\end{array}$ & $\begin{array}{c}21.4 \\
(123.9)\end{array}$ & $\begin{array}{c}-13.8 \\
(122.7)\end{array}$ & $\begin{array}{c}-64.2 \\
(152.7)\end{array}$ & $\begin{array}{l}19.6 \\
(120.9) \\
{[\$ 3,244]}\end{array}$ & $\begin{array}{c}-15.5 \\
(118.0)\end{array}$ & $\begin{array}{c}21.2 \\
(123.0)\end{array}$ \\
\hline Student-to-faculty ratio & $\begin{array}{l}-0.224 \\
(0.135)\end{array}$ & $\begin{array}{l}-0.224 \\
(0.135)\end{array}$ & $\begin{array}{l}-0.155 \\
(0.118)\end{array}$ & $\begin{array}{l}-0.151 \\
(0.204)\end{array}$ & $\begin{array}{c}-0.133 \\
(0.193) \\
{[\$ 1,691]}\end{array}$ & $\begin{array}{l}-0.255^{*} \\
(0.138)\end{array}$ & $\begin{array}{l}-0.222 \\
(0.133)\end{array}$ \\
\hline Graduation rate & $\begin{array}{c}0.814 \\
(0.530)\end{array}$ & $\begin{array}{c}0.814 \\
(0.530)\end{array}$ & $\begin{array}{c}0.645 \\
(0.432)\end{array}$ & $\begin{array}{c}0.667 \\
(0.709)\end{array}$ & $\begin{array}{c}0.796 \\
(0.633) \\
{[\$ 2,181]}\end{array}$ & $\begin{array}{c}0.983^{*} \\
(0.507)\end{array}$ & $\begin{array}{c}0.808 \\
(0.523)\end{array}$ \\
\hline In-state tuition and fees & $\begin{array}{c}162.1 \\
(135.7)\end{array}$ & $\begin{array}{c}162.1 \\
(135.7)\end{array}$ & $\begin{array}{c}143.9 \\
(123.7)\end{array}$ & $\begin{array}{c}197.2 \\
(146.8)\end{array}$ & $\begin{array}{l}319.5^{* * * *} \\
(90.0) \\
{[\$ 32,483]}\end{array}$ & $\begin{array}{c}204.4 \\
(138.1)\end{array}$ & $\begin{array}{c}166.4 \\
(135.2)\end{array}$ \\
\hline Out-of-state tuition and fees & $\begin{array}{c}149.5 \\
(134.6)\end{array}$ & $\begin{array}{c}149.5 \\
(134.6)\end{array}$ & $\begin{array}{l}148.4 \\
(99.0)\end{array}$ & $\begin{array}{c}117.3 \\
(190.8)\end{array}$ & $\begin{array}{l}201.2 \\
(149.9) \\
{[\$ 2,496]}\end{array}$ & $\begin{array}{c}173.7 \\
(130.6)\end{array}$ & $\begin{array}{c}150.8 \\
(132.0)\end{array}$ \\
\hline Tuition and fees, dependent on students' residency & $\begin{array}{c}217.3 \\
(140.1)\end{array}$ & $\begin{array}{c}217.3 \\
(140.1)\end{array}$ & $\begin{array}{c}203.5 \\
(131.6)\end{array}$ & $\begin{array}{c}284.5^{* *} \\
(136.9)\end{array}$ & $\begin{array}{l}372.6 * * * \\
(116.3) \\
{[\$ 8,217]}\end{array}$ & $\begin{array}{c}273.0^{*} \\
(142.9)\end{array}$ & $\begin{array}{c}221.1 \\
(138.3)\end{array}$ \\
\hline Carnegie: Very High or High Research & $\begin{array}{c}0.007 \\
(0.014)\end{array}$ & $\begin{array}{c}0.007 \\
(0.014)\end{array}$ & $\begin{array}{c}0.005 \\
(0.013)\end{array}$ & $\begin{array}{l}-0.016 \\
(0.019)\end{array}$ & $\begin{array}{c}0.002 \\
(0.015) \\
{[\$ 2,569]}\end{array}$ & $\begin{array}{c}0.009 \\
(0.014)\end{array}$ & $\begin{array}{c}0.006 \\
(0.014)\end{array}$ \\
\hline$N$ (maximum) & 28,340 & 35,192 & 28,340 & 14,324 & 22,826 & 28,340 & 28,340 \\
\hline
\end{tabular}

Notes: The table reports estimates of $\beta_{1}$ from Equation 1, applied to the binary incidence of college sector or measures of college quality. Column (1) displays results from our baseline specification, also found in Table 4 and in Table 5. Column (2) displays results when the estimating sample covers all high school graduates, including those who did not go to college. Column (3) illustrates results when covariates (cohort fixed effects and $X_{i}$ variables listed in Table 1) are included in Equation 1. Column (4) lists results when the bandwidth around the Pell eligibility threshold is narrowed from $\$ 3,000$ to $\$ 1,500$. Column (5) lists results under the optimal bandwidth for each outcome and subsample (Imbens \& Kalyanaraman, 2012). Column (6) lists results when we aggregate the EFC running variable to $\$ 500$ bins rather than $\$ 100$ bins. Column (7) lists results when a quadratic rather than a linear function is used for $E F C_{i c}-\bar{E}_{c}$, the gap between $i$ 's EFC and that cohort's Pell eligibility threshold. Robust standard errors, clustered by $\$ 100 \mathrm{EFC}$ bin, are in parentheses under each coefficient. Optimal bandwidths are in brackets below standard errors in Column (5).

$* p<0.1 ; * *<<0.05 ; * * * p<0.01$ 
TABLE 8: Regression discontinuity specification checks for college sector and college quality, males

\begin{tabular}{|c|c|c|c|c|c|c|c|}
\hline & $\begin{array}{c}\text { (1) } \\
\text { Baseline }\end{array}$ & $\begin{array}{c}(2) \\
\text { All HS } \\
\text { graduates }\end{array}$ & $\begin{array}{c}(3) \\
\text { With } \\
\text { covariates }\end{array}$ & $\begin{array}{c}(4) \\
\text { Narrow } \\
\text { BW }\end{array}$ & $\begin{array}{c}(5) \\
\text { Optimal } \\
\text { BW }\end{array}$ & $\begin{array}{c}(6) \\
\$ 500 \\
\text { EFC bins }\end{array}$ & $\begin{array}{c}\text { (7) } \\
\text { Quadratic }\end{array}$ \\
\hline Enrolled in a public TN two-year college & $\begin{array}{l}-0.025 \\
(0.020)\end{array}$ & $\begin{array}{l}-0.024 \\
(0.017)\end{array}$ & $\begin{array}{l}-0.020 \\
(0.019)\end{array}$ & $\begin{array}{l}-0.038 \\
(0.030)\end{array}$ & $\begin{array}{c}-0.02 \\
(0.023) \\
{[\$ 2,675]}\end{array}$ & $\begin{array}{l}-0.032 \\
(0.020)\end{array}$ & $\begin{array}{l}-0.025 \\
(0.020)\end{array}$ \\
\hline Enrolled in a public TN four-year college & $\begin{array}{c}0.017 \\
(0.020)\end{array}$ & $\begin{array}{c}0.008 \\
(0.017)\end{array}$ & $\begin{array}{c}0.009 \\
(0.019)\end{array}$ & $\begin{array}{c}0.017 \\
(0.030)\end{array}$ & $\begin{array}{c}0.019 \\
(0.020) \\
{[\$ 3,166]}\end{array}$ & $\begin{array}{c}0.021 \\
(0.021)\end{array}$ & $\begin{array}{c}0.017 \\
(0.020)\end{array}$ \\
\hline Enrolled in a public out-of-state two-year college & $\begin{array}{l}-0.001 \\
(0.004)\end{array}$ & $\begin{array}{l}-0.001 \\
(0.003)\end{array}$ & $\begin{array}{l}-1.6 \mathrm{E}-04 \\
(0.004)\end{array}$ & $\begin{array}{l}-0.003 \\
(0.006)\end{array}$ & $\begin{array}{r}0.003 \\
(0.003) \\
{[\$ 18,106]}\end{array}$ & $\begin{array}{l}3.7 \mathrm{E}-04 \\
(0.004)\end{array}$ & $\begin{array}{l}-0.001 \\
(0.004)\end{array}$ \\
\hline Enrolled in a public out-of-state four-year college & $\begin{array}{l}-0.007 \\
(0.009)\end{array}$ & $\begin{array}{l}-0.006 \\
(0.007)\end{array}$ & $\begin{array}{l}-0.005 \\
(0.009)\end{array}$ & $\begin{array}{l}-0.002 \\
(0.016)\end{array}$ & $\begin{array}{c}-0.008 \\
(0.009) \\
{[\$ 2,972]}\end{array}$ & $\begin{array}{l}-0.005 \\
(0.010)\end{array}$ & $\begin{array}{l}-0.007 \\
(0.009)\end{array}$ \\
\hline Enrolled in a private four-year college & $\begin{array}{c}0.013 \\
(0.010)\end{array}$ & $\begin{array}{c}0.008 \\
(0.008)\end{array}$ & $\begin{array}{c}0.013 \\
(0.010)\end{array}$ & $\begin{array}{c}0.025^{*} \\
(0.012)\end{array}$ & $\begin{array}{c}0.013 * \\
(0.007) \\
{[\$ 7,143]}\end{array}$ & $\begin{array}{c}0.012 \\
(0.010)\end{array}$ & $\begin{array}{c}0.013 \\
(0.010)\end{array}$ \\
\hline Enrolled in a private two-year college & $\begin{array}{c}0.004 * \\
(0.002)\end{array}$ & $\begin{array}{c}0.003^{*} \\
(0.002)\end{array}$ & $\begin{array}{c}0.004^{*} \\
(0.002)\end{array}$ & $\begin{array}{c}0.002 \\
(0.003)\end{array}$ & $\begin{array}{c}0.001 \\
(0.002) \\
{[\$ 4,463]}\end{array}$ & $\begin{array}{c}0.004^{*} \\
(0.002)\end{array}$ & $\begin{array}{c}0.004^{*} \\
(0.002)\end{array}$ \\
\hline ACT 25th percentile (or SAT equivalent) & $\begin{array}{l}0.217^{* *} \\
(0.103)\end{array}$ & $\begin{array}{l}0.217 * * \\
(0.103)\end{array}$ & $\begin{array}{c}0.185^{*} \\
(0.094)\end{array}$ & $\begin{array}{c}0.174 \\
(0.138)\end{array}$ & $\begin{array}{c}0.194 * \\
(0.112) \\
{[\$ 2,472]}\end{array}$ & $\begin{array}{l}0.212 * * \\
(0.096)\end{array}$ & $\begin{array}{l}0.219 * * \\
(0.102)\end{array}$ \\
\hline ACT 75th percentile (or SAT equivalent) & $\begin{array}{l}0.314^{* * * *} \\
(0.113)\end{array}$ & $\begin{array}{l}0.314 * * * \\
(0.113)\end{array}$ & $\begin{array}{l}0.284^{* *} \\
(0.107)\end{array}$ & $\begin{array}{c}0.242 \\
(0.151)\end{array}$ & $\begin{array}{c}0.293^{* *} \\
(0.114) \\
{[\$ 2,773]}\end{array}$ & $\begin{array}{l}0.305^{* * * *} \\
(0.106)\end{array}$ & $\begin{array}{l}0.317^{* * * *} \\
(0.114)\end{array}$ \\
\hline Instructional expenditures per FTE student & $\begin{array}{c}118.7 \\
(182.5)\end{array}$ & $\begin{array}{c}118.7 \\
(182.5)\end{array}$ & $\begin{array}{c}70.5 \\
(179.7)\end{array}$ & $\begin{array}{c}264.6 \\
(208.0)\end{array}$ & $\begin{array}{l}44.0 \\
(172.9) \\
{[\$ 3,971]}\end{array}$ & $\begin{array}{c}57.6 \\
(180.1)\end{array}$ & $\begin{array}{c}126.5 \\
(183.3)\end{array}$ \\
\hline Student-to-faculty ratio & $\begin{array}{l}-0.355^{*} \\
(0.195)\end{array}$ & $\begin{array}{l}-0.355^{*} \\
(0.195)\end{array}$ & $\begin{array}{l}-0.291 * \\
(0.174)\end{array}$ & $\begin{array}{l}-0.436 \\
(0.302)\end{array}$ & $\begin{array}{c}-0.263 \\
(0.263) \\
{[\$ 1,950]}\end{array}$ & $\begin{array}{l}-0.390^{*} \\
(0.198)\end{array}$ & $\begin{array}{l}-0.357 * \\
(0.191)\end{array}$ \\
\hline Graduation rate & $\begin{array}{c}1.109 \\
(0.829)\end{array}$ & $\begin{array}{c}1.109 \\
(0.829)\end{array}$ & $\begin{array}{c}0.847 \\
(0.764)\end{array}$ & $\begin{array}{c}1.037 \\
(1.178)\end{array}$ & $\begin{array}{c}1.291 \\
(1.009) \\
{[\$ 2,377]}\end{array}$ & $\begin{array}{l}1.278 \\
(0.797)\end{array}$ & $\begin{array}{c}1.122 \\
(0.809)\end{array}$ \\
\hline In-state tuition and fees & $\begin{array}{c}246.5 \\
(209.3)\end{array}$ & $\begin{array}{c}246.5 \\
(209.3)\end{array}$ & $\begin{array}{l}216.3 \\
(201.0)\end{array}$ & $\begin{array}{c}441.7 \\
(285.6)\end{array}$ & $\begin{array}{l}341.5 * * \\
(144.7) \\
{[\$ 9,905]}\end{array}$ & $\begin{array}{c}234.0 \\
(207.9)\end{array}$ & $\begin{array}{c}255.1 \\
(213.1)\end{array}$ \\
\hline Out-of-state tuition and fees & $\begin{array}{c}260.7 \\
(184.5)\end{array}$ & $\begin{array}{c}260.7 \\
(184.5)\end{array}$ & $\begin{array}{c}196.7 \\
(162.4)\end{array}$ & $\begin{array}{c}333.7 \\
(274.4)\end{array}$ & $\begin{array}{l}250.0 \\
(192.5) \\
{[\$ 2,875]}\end{array}$ & $\begin{array}{c}266.5 \\
(179.3)\end{array}$ & $\begin{array}{c}263.5 \\
(182.4)\end{array}$ \\
\hline Tuition and fees, dependent on students' residency & $\begin{array}{c}200.0 \\
(218.0)\end{array}$ & $\begin{array}{c}200.0 \\
(218.0)\end{array}$ & $\begin{array}{c}198.1 \\
(209.7)\end{array}$ & $\begin{array}{c}346.0 \\
(287.5)\end{array}$ & $\begin{array}{l}388.1 * * \\
(177.7) \\
{[\$ 4,808]}\end{array}$ & $\begin{array}{c}209.5 \\
(221.1)\end{array}$ & $\begin{array}{c}208.3 \\
(218.9)\end{array}$ \\
\hline Carnegie: Very High or High Research & $\begin{array}{c}0.009 \\
(0.019)\end{array}$ & $\begin{array}{c}0.009 \\
(0.019)\end{array}$ & $\begin{array}{c}0.004 \\
(0.019)\end{array}$ & $\begin{array}{l}-0.003 \\
(0.025)\end{array}$ & $\begin{array}{c}0.009 \\
(0.019) \\
{[\$ 3,065]}\end{array}$ & $\begin{array}{c}0.011 \\
(0.019)\end{array}$ & $\begin{array}{c}0.009 \\
(0.018)\end{array}$ \\
\hline$N$ (maximum) & 12,359 & 15,960 & 12,359 & 6,249 & 10,787 & 12,359 & 12,359 \\
\hline
\end{tabular}

Notes: The table reports estimates of $\beta_{1}$ from Equation 1, applied to the binary incidence of college sector or measures of college quality. The estimating sample is limited to males. Column (1) displays results from our baseline specification, also found in Table 4 and in Table 5. Column (2) displays results when the estimating sample covers all high school graduates, including those who did not go to college. Column (3) illustrates results when covariates (cohort fixed effects and $X_{i}$ variables listed in Table 1) are included in Equation 1. Column (4) lists results when the bandwidth around the Pell eligibility threshold is narrowed from $\$ 3,000$ to $\$ 1,500$. Column (5) lists results under the optimal bandwidth for each outcome and subsample (Imbens \& Kalyanaraman, 2012). Column (6) lists results when we aggregate the EFC running variable to $\$ 500$ bins rather than $\$ 100$ bins. Column (7) lists results when a quadratic rather than a linear function is used for $E F C_{i c}-\bar{E}_{c}$, the gap between $i$ 's EFC and that cohort's Pell eligibility threshold. Robust standard errors, clustered by $\$ 100$ EFC bin, are in parentheses under each coefficient. Optimal bandwidths are in brackets below standard errors in Column (5).

$* p<0.1 ; * *<0.05 ; * * * p<0.01$ 
TABLE 9: Regression discontinuity specification checks for college sector and college quality, females

\begin{tabular}{|c|c|c|c|c|c|c|c|}
\hline & $\begin{array}{c}\text { (1) } \\
\text { Baseline }\end{array}$ & $\begin{array}{c}\text { (2) } \\
\text { All HS } \\
\text { graduates }\end{array}$ & $\begin{array}{c}(3) \\
\text { With } \\
\text { covariates }\end{array}$ & $\begin{array}{c}(4) \\
\text { Narrow } \\
\text { BW }\end{array}$ & $\begin{array}{c}(5) \\
\text { Optimal } \\
\text { BW }\end{array}$ & $\begin{array}{c}(6) \\
\$ 500 \\
\text { EFC bins }\end{array}$ & $\begin{array}{c}\text { (7) } \\
\text { Quadratic }\end{array}$ \\
\hline Enrolled in a public TN two-year college & $\begin{array}{c}0.022 \\
(0.017)\end{array}$ & $\begin{array}{c}0.013 \\
(0.014)\end{array}$ & $\begin{array}{c}0.020 \\
(0.014)\end{array}$ & $\begin{array}{c}0.043^{*} \\
(0.024)\end{array}$ & $\begin{array}{c}0.016 \\
(0.018) \\
{[\$ 2,744]}\end{array}$ & $\begin{array}{c}0.017 \\
(0.017)\end{array}$ & $\begin{array}{c}0.022 \\
(0.017)\end{array}$ \\
\hline Enrolled in a public TN four-year college & $\begin{array}{l}-0.029 * \\
(0.017)\end{array}$ & $\begin{array}{l}-0.029 * \\
(0.016)\end{array}$ & $\begin{array}{l}-0.025^{*} \\
(0.014)\end{array}$ & $\begin{array}{l}-0.058 * * \\
(0.023)\end{array}$ & $\begin{array}{c}-0.034^{*} \\
(0.018) \\
{[\$ 2,599]}\end{array}$ & $\begin{array}{l}-0.029 * \\
(0.017)\end{array}$ & $\begin{array}{l}-0.029^{*} \\
(0.017)\end{array}$ \\
\hline Enrolled in a public out-of-state two-year college & $\begin{array}{c}0.004 \\
(0.003)\end{array}$ & $\begin{array}{c}0.003 \\
(0.003)\end{array}$ & $\begin{array}{c}0.004 \\
(0.003)\end{array}$ & $\begin{array}{c}0.001 \\
(0.004)\end{array}$ & $\begin{array}{c}-0.001 \\
(0.002) \\
{[\$ 5,366]}\end{array}$ & $\begin{array}{c}0.004 \\
(0.003)\end{array}$ & $\begin{array}{c}0.004 \\
(0.003)\end{array}$ \\
\hline Enrolled in a public out-of-state four-year college & $\begin{array}{c}0.011^{*} \\
(0.006)\end{array}$ & $\begin{array}{c}0.009^{*} \\
(0.005)\end{array}$ & $\begin{array}{c}0.009^{*} \\
(0.006)\end{array}$ & $\begin{array}{l}0.017 * * \\
(0.007)\end{array}$ & $\begin{array}{c}0.004 \\
(0.004) \\
{[\$ 9,307]}\end{array}$ & $\begin{array}{c}0.012^{* *} \\
(0.006)\end{array}$ & $\begin{array}{c}0.011^{*} \\
(0.006)\end{array}$ \\
\hline Enrolled in a private four-year college & $\begin{array}{l}-0.008 \\
(0.010)\end{array}$ & $\begin{array}{l}-0.008 \\
(0.008)\end{array}$ & $\begin{array}{l}-0.008 \\
(0.010)\end{array}$ & $\begin{array}{l}-0.004 \\
(0.015)\end{array}$ & $\begin{array}{r}-0.009 \\
(0.006) \\
{[\$ 15,413]}\end{array}$ & $\begin{array}{l}-0.004 \\
(0.010)\end{array}$ & $\begin{array}{l}-0.008 \\
(0.010)\end{array}$ \\
\hline Enrolled in a private two-year college & $\begin{array}{l}1.5 \mathrm{E}-04 \\
(0.002)\end{array}$ & $\begin{array}{l}5.0 \mathrm{E}-05 \\
(0.001)\end{array}$ & $\begin{array}{c}0.001 \\
(0.002)\end{array}$ & $\begin{array}{l}4.9 \mathrm{E}-04 \\
(0.002)\end{array}$ & $\begin{array}{c}4.0 \mathrm{E}-04 \\
(0.002) \\
{[\$ 2,801]}\end{array}$ & $\begin{array}{l}\text { 4.8E-04 } \\
(0.002)\end{array}$ & $\begin{array}{l}1.6 \mathrm{E}-04 \\
(0.002)\end{array}$ \\
\hline ACT 25th percentile (or SAT equivalent) & $\begin{array}{c}0.031 \\
(0.085)\end{array}$ & $\begin{array}{c}0.031 \\
(0.085)\end{array}$ & $\begin{array}{c}0.024 \\
(0.070)\end{array}$ & $\begin{array}{l}-0.001 \\
(0.112)\end{array}$ & $\begin{array}{c}0.051 \\
(0.093) \\
{[\$ 2,262]}\end{array}$ & $\begin{array}{c}0.048 \\
(0.080)\end{array}$ & $\begin{array}{c}0.027 \\
(0.086)\end{array}$ \\
\hline ACT 75th percentile (or SAT equivalent) & $\begin{array}{l}-0.043 \\
(0.105)\end{array}$ & $\begin{array}{l}-0.043 \\
(0.105)\end{array}$ & $\begin{array}{l}-0.055 \\
(0.084)\end{array}$ & $\begin{array}{l}-0.009 \\
(0.151)\end{array}$ & $\begin{array}{c}0.028 \\
(0.117) \\
{[\$ 2,494]}\end{array}$ & $\begin{array}{l}-0.013 \\
(0.099)\end{array}$ & $\begin{array}{l}-0.047 \\
(0.107)\end{array}$ \\
\hline Instructional expenditures per FTE student & $\begin{array}{c}-54.5 \\
(190.3)\end{array}$ & $\begin{array}{c}-54.5 \\
(190.3)\end{array}$ & $\begin{array}{c}-91.8 \\
(185.7)\end{array}$ & $\begin{array}{l}-322.7 \\
(221.7)\end{array}$ & $\begin{array}{l}-86.2 \\
(178.1) \\
{[\$ 3,392]}\end{array}$ & $\begin{array}{c}-71.7 \\
(191.0)\end{array}$ & $\begin{array}{c}-62.5 \\
(192.4)\end{array}$ \\
\hline Student-to-faculty ratio & $\begin{array}{l}-0.123 \\
(0.153)\end{array}$ & $\begin{array}{l}-0.123 \\
(0.153)\end{array}$ & $\begin{array}{l}-0.034 \\
(0.135)\end{array}$ & $\begin{array}{c}0.071 \\
(0.198)\end{array}$ & $\begin{array}{c}0.005 \\
(0.187) \\
{[\$ 1,853]}\end{array}$ & $\begin{array}{l}-0.15 \\
(0.154)\end{array}$ & $\begin{array}{l}-0.117 \\
(0.156)\end{array}$ \\
\hline Graduation rate & $\begin{array}{c}0.575 \\
(0.617)\end{array}$ & $\begin{array}{c}0.575 \\
(0.617)\end{array}$ & $\begin{array}{c}0.462 \\
(0.537)\end{array}$ & $\begin{array}{c}0.391 \\
(0.778)\end{array}$ & $\begin{array}{c}0.927 \\
(0.640) \\
{[\$ 2,500]}\end{array}$ & $\begin{array}{c}0.744 \\
(0.607)\end{array}$ & $\begin{array}{c}0.549 \\
(0.631)\end{array}$ \\
\hline In-state tuition and fees & $\begin{array}{c}100.2 \\
(185.1)\end{array}$ & $\begin{array}{c}100.2 \\
(185.1)\end{array}$ & $\begin{array}{c}90.0 \\
(184.4)\end{array}$ & $\begin{array}{c}6.0 \\
(227.9)\end{array}$ & $\begin{array}{l}199.5 \\
(146.1) \\
{[\$ 11,950]}\end{array}$ & $\begin{array}{c}185.4 \\
(193.4)\end{array}$ & $\begin{array}{c}100.6 \\
(187.5)\end{array}$ \\
\hline Out-of-state tuition and fees & $\begin{array}{c}61.5 \\
(156.6)\end{array}$ & $\begin{array}{c}61.5 \\
(156.6)\end{array}$ & $\begin{array}{c}108.8 \\
(122.9)\end{array}$ & $\begin{array}{c}-52.1 \\
(194.9)\end{array}$ & $\begin{array}{l}198.1 \\
(159.9) \\
{[\$ 2,731]}\end{array}$ & $\begin{array}{c}100.4 \\
(155.4)\end{array}$ & $\begin{array}{c}61.3 \\
(156.1)\end{array}$ \\
\hline Tuition and fees, dependent on students' residency & $\begin{array}{c}234.0 \\
(207.8)\end{array}$ & $\begin{array}{c}234.0 \\
(207.8)\end{array}$ & $\begin{array}{c}210.0 \\
(212.9)\end{array}$ & $\begin{array}{c}239.6 \\
(264.9)\end{array}$ & $\begin{array}{l}387.2 * * \\
(178.8) \\
{[\$ 7,182]}\end{array}$ & $\begin{array}{c}326.4 \\
(214.0)\end{array}$ & $\begin{array}{c}233.7 \\
(211.2)\end{array}$ \\
\hline Carnegie: Very High or High Research & $\begin{array}{c}0.005 \\
(0.018)\end{array}$ & $\begin{array}{c}0.005 \\
(0.018)\end{array}$ & $\begin{array}{c}0.003 \\
(0.017)\end{array}$ & $\begin{array}{l}-0.026 \\
(0.023)\end{array}$ & $\begin{array}{c}0.005 \\
(0.019) \\
{[\$ 2,763]}\end{array}$ & $\begin{array}{c}0.006 \\
(0.018)\end{array}$ & $\begin{array}{c}0.004 \\
(0.018)\end{array}$ \\
\hline$N$ (maximum) & 15,981 & 19,232 & 15,981 & 8,075 & 14,975 & 15,981 & 15,981 \\
\hline
\end{tabular}

Notes: The table reports estimates of $\beta_{1}$ from Equation 1, applied to the binary incidence of college sector or measures of college quality. The estimating sample is limited to females. Column (1) displays results from our baseline specification, also found in Table 4 and in Table 5. Column (2) displays results when the estimating sample covers all high school graduates, including those who did not go to college. Column (3) illustrates results when covariates (cohort fixed effects and $X_{i}$ variables listed in Table 1) are included in Equation 1. Column (4) lists results when the bandwidth around the Pell eligibility threshold is narrowed from $\$ 3,000$ to $\$ 1,500$. Column (5) lists results under the optimal bandwidth for each outcome and subsample (Imbens \& Kalyanaraman, 2012). Column (6) lists results when we aggregate the EFC running variable to $\$ 500$ bins rather than $\$ 100$ bins. Column (7) lists results when a quadratic rather than a linear function is used for $E F C_{i c}-\bar{E}_{c}$, the gap between $i$ 's EFC and that cohort's Pell eligibility threshold. Robust standard errors, clustered by $\$ 100$ EFC bin, are in parentheses under each coefficient. Optimal bandwidths are in brackets below standard errors in Column (5).

$* p<0.1 ; * *<<0.05 ; * * * p<0.01$ 
TABLE 10: Conditional independence assumption specification checks

\begin{tabular}{|c|c|c|}
\hline & $\begin{array}{l}(1) \\
\text { Coefficient on } E F C_{i c}-\bar{E}_{c}\end{array}$ & $\begin{array}{l}(2) \\
\text { (St. Err.) }\end{array}$ \\
\hline Enrolled in any college & $-3.2 \mathrm{E}-04$ & $(0.003)$ \\
\hline Enrolled in a public TN two-year college & -0.006 & $(0.005)$ \\
\hline Enrolled in a public TN four-year college & -0.001 & $(0.005)$ \\
\hline Enrolled in a public out-of-state two-year college & 0.001 & $(0.001)$ \\
\hline Enrolled in a public out-of-state four-year college & $0.006^{* * *}$ & $(0.002)$ \\
\hline Enrolled in a private four-year college & $-1.4 \mathrm{E}-04$ & $(0.004)$ \\
\hline Enrolled in a private two-year college & 0.001 & $(0.001)$ \\
\hline ACT 25th percentile (or SAT equivalent) & 0.039 & $(0.027)$ \\
\hline ACT 75th percentile (or SAT equivalent) & 0.049 & $(0.032)$ \\
\hline Instructional expenditures per FTE student & -86.5 & $(60.8)$ \\
\hline Student-faculty ratio & -0.048 & $(0.056)$ \\
\hline Graduation rate & 0.181 & $(0.184)$ \\
\hline In-state tuition and fees & 2.8 & $(60.2)$ \\
\hline Out-of-state tuition and fees & -41.0 & $(45.3)$ \\
\hline Tuition and fees, dependent on students' residency & 67.7 & $(62.5)$ \\
\hline Carnegie: Very High or High Research & 0.002 & $(0.005)$ \\
\hline \multicolumn{3}{|c|}{$\begin{array}{l}\text { Notes: The table reports estimates of } \pi \text { from Equation 2, applied to the binary incidence of college } \\
\text { enrollment, binary college sector outcomes, or college quality measures. Outcomes } Y_{i c} \text { for stu- } \\
\text { dents } i \text {, cohort } c \text { are regressed against observable characteristics }\left(X_{i c}: \text { real family adjusted gross }\right. \\
\text { income (AGI), the EFC-AGI ratio, mothers' and fathers' college education, race, gender, first ACT } \\
\text { composite score, the number of ACT attempts made, a binary indicator for missing ACT data) and } \\
E F C_{i c}-\bar{E}_{c} \text {, the gap between } i \text { 's EFC and that cohort's Pell eligibility threshold. Standard errors } \\
\text { are listed in parentheses beside each coefficient. } \\
* p<0.1 ; * * p<0.05 ; * * * p<0.01\end{array}$} \\
\hline
\end{tabular}


TABLE 11: Treatment effect estimates for outcomes below the eligibility threshold

\begin{tabular}{|c|c|c|c|c|c|}
\hline & $\begin{array}{c}(1) \\
\text { All students }\end{array}$ & $\begin{array}{c}(2) \\
\text { Male students } \\
\end{array}$ & $\begin{array}{c}\text { (3) } \\
\text { Female students } \\
\end{array}$ & $\begin{array}{c}(4) \\
\text { White students }\end{array}$ & $\begin{array}{c}(5) \\
\text { Black students }\end{array}$ \\
\hline Any college enrollment & $\begin{array}{l}-0.003 \\
(0.006)\end{array}$ & $\begin{array}{l}-0.004 \\
(0.009)\end{array}$ & $\begin{array}{c}0.007 \\
(0.009)\end{array}$ & $\begin{array}{l}-0.007 \\
(0.006)\end{array}$ & $\begin{array}{c}0.001 \\
(0.018)\end{array}$ \\
\hline Enrolled in a public TN two-year college & $\begin{array}{l}-0.004 \\
(0.008)\end{array}$ & $\begin{array}{l}-0.016 \\
(0.012)\end{array}$ & $\begin{array}{l}-0.004 \\
(0.012)\end{array}$ & $\begin{array}{l}-0.010 \\
(0.009)\end{array}$ & $\begin{array}{c}0.003 \\
(0.021)\end{array}$ \\
\hline Enrolled in a public TN four-year college & $\begin{array}{l}-0.002 \\
(0.009)\end{array}$ & $\begin{array}{c}0.004 \\
(0.013)\end{array}$ & $\begin{array}{c}0.006 \\
(0.013)\end{array}$ & $\begin{array}{l}-0.003 \\
(0.010)\end{array}$ & $\begin{array}{c}0.017 \\
(0.024)\end{array}$ \\
\hline Enrolled in a public out-of-state two-year college & $\begin{array}{l}-0.001 \\
(0.002)\end{array}$ & $\begin{array}{c}0.005 \\
(0.003)\end{array}$ & $\begin{array}{l}-0.005 \\
(0.003)\end{array}$ & $\begin{array}{c}0.002 \\
(0.002)\end{array}$ & $\begin{array}{l}-0.008 \\
(0.008)\end{array}$ \\
\hline Enrolled in a public out-of-state four-year college & $\begin{array}{l}-0.005 \\
(0.004)\end{array}$ & $\begin{array}{l}-0.013 * * \\
(0.006)\end{array}$ & $\begin{array}{c}0.003 \\
(0.005)\end{array}$ & $\begin{array}{l}-0.004 \\
(0.004)\end{array}$ & $\begin{array}{l}-0.002 \\
(0.013)\end{array}$ \\
\hline Enrolled in a private four-year college & $\begin{array}{c}0.011^{*} \\
(0.006)\end{array}$ & $\begin{array}{l}0.019 * * \\
(0.009)\end{array}$ & $\begin{array}{c}0.003 \\
(0.009)\end{array}$ & $\begin{array}{l}0.013 * * \\
(0.007)\end{array}$ & $\begin{array}{c}0.001 \\
(0.016)\end{array}$ \\
\hline Enrolled in a private two-year college & $\begin{array}{l}2.3 \mathrm{E}-04 \\
(0.001)\end{array}$ & $\begin{array}{c}0.002 \\
(0.002)\end{array}$ & $\begin{array}{l}-0.002 \\
(0.002)\end{array}$ & $\begin{array}{l}0.002 * * \\
(0.001)\end{array}$ & $\begin{array}{l}-0.011^{*} \\
(0.007)\end{array}$ \\
\hline ACT 25th percentile (or SAT equivalent) & $\begin{array}{c}0.074 \\
(0.046)\end{array}$ & $\begin{array}{c}0.107 \\
(0.071)\end{array}$ & $\begin{array}{c}0.032 \\
(0.067)\end{array}$ & $\begin{array}{l}0.131^{* * * *} \\
(0.047)\end{array}$ & $\begin{array}{l}-0.112 \\
(0.143)\end{array}$ \\
\hline ACT 75th percentile (or SAT equivalent) & $\begin{array}{c}0.068 \\
(0.053)\end{array}$ & $\begin{array}{c}0.112 \\
(0.083)\end{array}$ & $\begin{array}{c}0.024 \\
(0.078)\end{array}$ & $\begin{array}{l}0.121^{* *} \\
(0.056)\end{array}$ & $\begin{array}{l}-0.057 \\
(0.162)\end{array}$ \\
\hline Instructional expenditures per FTE student & $\begin{array}{c}228.9 \\
(147.3)\end{array}$ & $\begin{array}{c}330.9^{*} \\
(177.5)\end{array}$ & $\begin{array}{l}-116.9 \\
(156.5)\end{array}$ & $\begin{array}{l}307.0^{* * *} \\
(146.3)\end{array}$ & $\begin{array}{l}-347.3 \\
(330.3)\end{array}$ \\
\hline Student-to-faculty ratio & $\begin{array}{l}-0.081 \\
(0.088)\end{array}$ & $\begin{array}{l}-0.117 \\
(0.124)\end{array}$ & $\begin{array}{c}0.062 \\
(0.138)\end{array}$ & $\begin{array}{l}-0.135 \\
(0.095)\end{array}$ & $\begin{array}{c}0.211 \\
(0.292)\end{array}$ \\
\hline Graduation rate & $\begin{array}{c}0.537^{*} \\
(0.301)\end{array}$ & $\begin{array}{c}0.678 \\
(0.461)\end{array}$ & $\begin{array}{c}0.488 \\
(0.463)\end{array}$ & $\begin{array}{l}0.820^{* * *} \\
(0.328)\end{array}$ & $\begin{array}{l}-0.553 \\
(0.834)\end{array}$ \\
\hline In-state tuition and fees & $\begin{array}{l}261.1 * * \\
(106.8)\end{array}$ & $\begin{array}{l}388.6^{* * *} \\
(149.7)\end{array}$ & $\begin{array}{c}96.6 \\
(145.4)\end{array}$ & $\begin{array}{l}341.1^{* * * *} \\
(112.7)\end{array}$ & $\begin{array}{l}-194.5 \\
(287.0)\end{array}$ \\
\hline Out-of-state tuition and fees & $\begin{array}{l}299.3 * * * \\
(75.7)\end{array}$ & $\begin{array}{l}334.2^{* * * *} \\
(112.2)\end{array}$ & $\begin{array}{l}318.7 * * * \\
(114.3)\end{array}$ & $\begin{array}{l}347.4 * * * \\
(78.9)\end{array}$ & $\begin{array}{c}242.7 \\
(232.6)\end{array}$ \\
\hline Tuition and fees, dependent on students' residency & $\begin{array}{l}213.6^{*} \\
(111.6)\end{array}$ & $\begin{array}{c}289.6^{*} \\
(160.2)\end{array}$ & $\begin{array}{c}91.4 \\
(151.3)\end{array}$ & $\begin{array}{l}311.7 \text { *** } \\
(118.2)\end{array}$ & $\begin{array}{l}-207.7 \\
(299.5)\end{array}$ \\
\hline Carnegie: Very High or High Research & $\begin{array}{l}-0.004 \\
(0.008)\end{array}$ & $\begin{array}{l}-0.002 \\
(0.012)\end{array}$ & $\begin{array}{l}-0.004 \\
(0.013)\end{array}$ & $\begin{array}{l}-0.007 \\
(0.008)\end{array}$ & $\begin{array}{c}0.024 \\
(0.024)\end{array}$ \\
\hline
\end{tabular}

Notes: $N=35,073$ high school graduates for any college enrollment and 28,250 college-going students for other outcomes. The table reports treatment effect estimates for outcomes below the eligibility threshold and are calculated as described in Section 4.3. Column (1) lists results for all students which are the same as those presented in Figures 4, 5, and 6. Columns (2) through (5) list results by subgroups of students. The estimating sample for any college enrollment includes all high school graduates while the estimating sample is restricted to college-going students for outcomes regarding college sector and college quality. Standard errors are calculated following Kline (2011) and are in parentheses under each coefficient.

$* p<0.1 ; * * p<0.05 ; * * * p<0.01$ 